\title{
Gap Junctions/Hemichannels Modulate Interkinetic Nuclear Migration in the Forebrain Precursors
}

\author{
Xiuxin Liu, Kazue Hashimoto-Torii, Masaaki Torii, Chen Ding, and Pasko Rakic \\ Department of Neurobiology and Kavli Institute for Neuroscience, Yale University School of Medicine, New Haven, Connecticut 06510
}

During mitotic division in the telencephalic proliferative ventricular zone (VZ), the nuclei of the neural precursors move basally away from the ventricular surface for DNA synthesis, and apically return to the surface for mitotic division; a process known as interkinetic migration or "to-and-fro" nuclear translocation. The cell, which remains attached to the ventricular surface, either continues cycling, or exits the cycle and migrates to the subventricular zone or the developing cortical plate. Although gap junctions/hemichannels are known to modulate DNA synthesis via $\mathrm{Ca}^{2+}$ waves, the role of $\mathrm{Ca}^{+}$oscillations and the mechanism of nuclear translocation in the $\mathrm{VZ}$ precursors are unclear. Here, we provide evidence that, during apical nuclear migration, VZ precursors display dynamic spontaneous $\mathrm{Ca}^{2+}$ transients, which depend on functional gap junctions/hemichannels via ATP release and $\mathrm{Ca}^{2+}$-mobilizing messenger diffusion. Furthermore, we found that blocking gap junctions/hemichannels or short hairpin RNA-mediated knockdown of Cx43 (connexin 43) retards the apically directed interkinetic nuclear migration accompanied with changes in the nuclear length/width ratio. In addition, we demonstrated that blocking functional gap junctions/hemichannels induces phosphorylation of small GTPase cdc42 in the VZ precursors. The basal phase of interkinetic migration is much slower and appears to be mediated passively by mechanical forces after cell division. Our findings indicate that functional interference with gap junctions/hemichannels during embryonic development may lead to abnormal corticogenesis and dysfunction of the cerebral cortex in adult organisms.

\section{Introduction}

During forebrain development, the cortical projection neurons are generated from the neural precursors in the embryonic proliferative ventricular zone (VZ)/subventricular zone (SVZ) and migrate radially to the overlaying cortical plate. This process includes DNA synthesis, nuclear translocation, cell division, phenotypic commitment, and migration to its final destination (Rakic, 1988b). Although oscillatory, alternating interkinetic (toand-fro) nuclear migration during cell division, which requires the rearrangement of cytoplasmic tubular and filamentous organelles (Alexandre et al., 1989; Solecki et al., 2004; Xie et al., 2007; Del Bene et al., 2008), has been known for $>70$ years (Watterson, 1966), the significance and molecular mechanism orchestrating this dynamic process is not well understood (Sidman and Rakic, 1973; Métin et al., 2008).

Similar to other developing pseudostratified epithelia, such as the neural tube or lens placode, in which mitotic division occurs at the surface, cell nuclei are thought to be passively displaced away from the surface during their DNA synthesis phase before returning actively to the surface to divide again (Langman et al., 1966; Zwann et al., 1969). The significance of this widespread

Received Aug. 24, 2009; revised Jan. 8, 2010; accepted Jan. 18, 2010.

This work was supported by funding from the National Institutes of Health and the Kavli Institute for Neuroscience (P.R.) and a fellowship award from National Alliance for Autism Research/Autism Speaks (X.L.). C.D. was a summer intern student. We thank the constructive discussion with Dr. Yuguo Yu and thoughtful comments provided by Drs. Josh Breunig, Albert E. Ayoub, Martin Dominguez, Mladen-Roko Rasin, and Nenad Sestan. We are also grateful to Mariamma Pappy, Anita Begovic, and Adi Begovic for the technical support.

Correspondence should be addressed to Pasko Rakic at the above address. E-mail: pasko.rakic@yale.edu.

DOI:10.1523/JNEUROSCI.4187-09.2010

Copyright $\odot 2010$ the authors $\quad 0270-6474 / 10 / 304197-13 \$ 15.00 / 0$ nuclear translocation is not clear, apart from being necessary to avoid overcrowding of the multiplying nuclei at the surface. Since the formation of the laminar cerebral cortex depends on temporarily coordinated production of neurons in the VZ/SVZ, which requires a precise control of cell cycles, it is particularly important to learn more about the mechanism of apical nuclear translocation. So far, it has been well established that neuronal precursors in the VZ are extensively coupled in radial columnar clusters via gap junctions (LoTurco and Kriegstein, 1991; Bahrey and Moody, 2003), which enables the coupled proliferative unit to act as a syncytium via direct metabolic and electrical communication. Consistent with these observations, connexins (Cxs), the subunits of the connexons (hemichannels) and gap junctions, are expressed in the embryonic cerebral cortex (Belliveau and Naus, 1995; Bittman et al., 1997; Nadarajah et al., 1997; Buniello et al., 2004; Oyamada et al., 2005). More specifically, their expression varies according to phase of the cell cycle and developmental stage (Bittman et al., 1997; Nadarajah et al., 1997; Oyamada et al., 2005). Recently, it has been demonstrated that both the extracellular adhesive domain and the intracellular C terminal of Cx43 play an essential role in cortical neuronal migration (Elias et al., 2007; Cina et al., 2009). Since Cxs are predominantly expressed within the proliferative $\mathrm{VZ}$ during the period of neurogenesis, it is expected that they would play an important role in maintaining the neural progenitor pool by controlling its self-renewal.

It is also well established that functional gap junctions/ hemichannels are involved in the propagation of $\mathrm{Ca}^{2+}$ waves in the embryonic proliferative zones (Weissman et al., 2004) and that their pharmacological blocking abolishes these $\mathrm{Ca}^{2+}$ waves, thereby preventing DNA synthesis in the neural precur- 
sors (Bittman et al., 1997; Weissman et al., 2004; Liu et al., 2008). Furthermore, disorganization of the VZ/SVZ in the GFAP-Cre/ floxed $\mathrm{Cx} 43$ conditional knock-out mice indicates the involvement of gap junctions/hemichannels in neurogenesis and neuronal migration (Wiencken-Barger et al., 2007). After each round of DNA replication, the nuclei of the VZ precursors are pulled down by the assembled microtubules attached to the centrosome located at the ventricular surface (Xie et al., 2007). This nuclear movement in apical direction is associated with changes in the cytoskeleton controlled by small molecular Rho-GTPases (Cappello et al., 2006; Heasman and Ridley, 2008), which are, in turn, regulated by intracellular $\mathrm{Ca}^{2+}$ signaling (Price et al., 2003; Jin et al., 2005). In the present study, we examined the specific role of gap junctions/hemichannels in regulation of $\mathrm{Ca}^{2+}$ signaling and their effect on the apically directed interkinetic nuclear migration of the precursors in the VZ during cortical neurogenesis.

\section{Materials and Methods}

Solutions and pharmacological agents. The artificial CSF (ACSF) contains the following (in mM): $125 \mathrm{NaCl}, 2.5 \mathrm{KCl}, 1.25 \mathrm{NaH}_{2} \mathrm{PO}_{4}, 1 \mathrm{MgCl}_{2}, 2$ $\mathrm{CaCl}_{2}, 25 \mathrm{NaHCO}_{3}$, and 10 glucose. The osmolarity is $\sim 310 \mathrm{mOsm} / \mathrm{L}$ and $\mathrm{pH}$ is 7.4 when bubbled with $95 \% \mathrm{O}_{2} / 5 \% \mathrm{CO}_{2}$. The $0 \mathrm{mM} \mathrm{Ca}^{2+} \mathrm{ACSF}$ was prepared by replacing the $\mathrm{Ca}^{2+}$ with equal millimolar EGTA. The HEPES solution contains the following (in $\mathrm{mM}$ ): $156 \mathrm{NaCl}, 2.5 \mathrm{KCl}, 2 \mathrm{CaCl}_{2}$, $1 \mathrm{MgCl}_{2}, 15$ glucose, and 10 HEPES, $\mathrm{pH}$ adjusted to 7.4 with $1 \mathrm{~N} \mathrm{NaOH}$. The following drugs were used: ATP $(0.1-100 \mu \mathrm{M})$, suramin $(100 \mu \mathrm{M})$, meclofenamic acid (MFA) $(60,100 \mu \mathrm{M})$, carbenoxolone (CBX) (100 $\mu \mathrm{M})$, 2-methylthioadenosine $5^{\prime}$-triphosphate (Mes-ATP) $(100 \mu \mathrm{M}), 2$-APB (50 $\mu \mathrm{M}), 18$ - $\alpha$-glycerrhetinic acid $(40 \mu \mathrm{M})$, iso-pyridoxal-5'-phosphate-6azophenyl-2',5'-disulfonate (PPADS), 4,4'-diisothiocyanatostilbene-2,2'disulfonic acid (DIDS), and indomethacin $(100 \mu \mathrm{M})$; all are Sigma-Aldrich products except Hoechst $(10 \mu \mathrm{M}), o$-nitrophenyl-EGTA acetoxymethyl ester (NP-EGTA AM) $(5 \mu \mathrm{M})$, and BAPTA-AM ( $50 \mu \mathrm{M}$; Invitrogen, respectively).

Tissue preparation. All experimental procedures were in accordance with the animal welfare guidelines of Yale University on the ethical use of animals for experimentation. Timed pregnant CD-1 mice (Charles River) at embryonic day 14 (E14) to E16 were used in this study. After rapid decapitation, the embryo brain was removed and put in cold balanced Hanks solution and then placed into 3\% agarose (type VII; SigmaAldrich). Agarose was allowed to solidify on ice (2-3 min), and coronal sections were made at $300 \mu \mathrm{m}$ in cold ACSF using the vibratome (Vibratome). Slices were placed in oxygenized ACSF and recovered at room temperature for $30 \mathrm{~min}$.

Time-lapse live imaging, calcium imaging, and data analysis. Timelapse live imaging and calcium imaging were performed as previously described (De Mello, 1983; Weissman et al., 2004; Pearson et al., 2005; Liu et al., 2008). Slices were transferred to oxygenized ACSF containing calcium indicator Fluo-4 (Fluo-4 AM) (10 $\mu \mathrm{M}$; Invitrogen) and incubated at $37^{\circ} \mathrm{C}$ for $30 \mathrm{~min}$. The mean fluorescence of individual cells was calculated and normalized to its initial value at time $0\left(F / F_{0}\right)$. A change in fluorescence in excess of a criterion level of $10 \%$ above baseline was accepted as a response or $\mathrm{Ca}^{2+}$ transients. The changes of average frequency and amplitude $\left(F / F_{0}\right)$ of $\mathrm{Ca}^{2+}$ transients in the same view field were used to determine the effect of drugs before and during drug application. Power spectral analysis was performed in the normalized $\mathrm{Ca}^{2+}$ signaling $\left(F / F_{0}\right)$ with the software provided by OriginLab. The sampling interval was set at $3 \mathrm{~s}$ and Hanning window was used as a filter. The nuclear motility and migration were detected by nuclear labeling with Hoechst ( $10 \mu \mathrm{m}$; Invitrogen) at $37^{\circ} \mathrm{C}$ for $30 \mathrm{~min}$.

Patch-clamp recordings. Patch-clamp recording was as previously described (Liu et al., 2005). Whole-cell patch-clamp recordings were obtained as previously described (Liu et al., 2005, 2006). Patch pipettes were pulled from thin-walled borosilicate glass (outer diameter, $1.55 \mathrm{~mm}$; internal diameter, $1.2 \mathrm{~mm}$; WPI; TW150F-40) on a PP-83 puller (Narishige). Pipettes had resistances of 3-6 $\mathrm{M} \Omega$ when filled with the intracellular solution. For intracellular labeling, $0.1 \%$ Lucifer yellow (dilithium salt) was added to the pipette solution. Recordings were performed using an Axopatch-200B amplifier (Molecular Devices). Current signals were low-pass filtered at $2-5 \mathrm{kHz}$ and digitized on-line at $5-20 \mathrm{kHz}$ using a Digidata 1320 digitizing board (Molecular Devices) interfaced with a Dell computer.

Lucifer yellow uptake. Slices were loaded with NP-EGTA AM $(5 \mu \mathrm{M})$ for $30 \mathrm{~min}$ at $37^{\circ} \mathrm{C}$, and then transferred to the chamber perfused with oxygenized ACSF. One hemisphere of the neocortex was then subjected to UV bleaching for $2 \mathrm{~s}$ with $10 \mathrm{~s}$ interval for five times. During bleaching, the perfusate was replaced by HEPES solution containing Lucifer yellow $(5 \mathrm{mg} / \mathrm{ml})$. For dye uptake blocking experiments, MFA $(100 \mu \mathrm{M})$ was included in the perfusate before and during UV bleaching. Some slices were fixed in $4 \%$ paraformaldehyde (PFA) and then resectioned in 20 $\mu \mathrm{m}$ for fluorescence detection. Lucifer yellow fluorescence was detected in both hemispheres under bleaching and unbleaching; normalized pixel densities were used for quantification.

ATP bioluminescence measurement and biosensor detection. ATP released from the perfused slices was measured using ATP bioluminescence detection kit (ENLITEN ATP assay system; Promega). Frontal embryonic brain slices containing the neocortex were perfused with oxygenized ACSF in a self-made perfusion system (1-1.2 $\mathrm{ml} / 5 \mathrm{~min})$. The perfusate was continuously collected every $5 \mathrm{~min}$. Fifty microliters of perfusate and $50 \mu \mathrm{l}$ of ATP assay agent were mixed and the luminescence was measured in the ENLITEN 20 luminometer. Standard curve showed high sensitivity and good correlation at $10^{-12}$ to $10^{-7}$ M ATP $(r=$ 0.9999) (supplemental Fig. S1 A, available at www.jneurosci.org as supplemental material).

To detect spontaneous ATP release from the VZ/SVZ cells of the neocortex, low-density cultured GL261 cells on coverslips were labeled with Hoechst $(1 \mu \mathrm{g} / \mathrm{ml})$ and loaded with $\mathrm{Ca}^{2+}$ indicator Fluor- 4 and then put in the recording chamber mounted on the inverted confocal microscope (LSM 510; Zeiss). Coronal sectioned slices from the embryonic brain (E15) were overlaid on the coverslips. After a recovery period of at least $30 \mathrm{~min}, \mathrm{Ca}^{2+}$ signaling was recorded in GL261 cells corresponding to the region of the VZ/SVZ identified under the differential interference contrast.

Two-photon single-cell stimulation and $\mathrm{Ca}^{2+}$ signaling propagation. Fluo-4-loaded embryonic brain slices were transferred to a recording chamber on the stage of inverted Zeiss LSM 510 confocal microscope and continuously perfused with oxygenized ASCF. The stimulation target cells under the slice surface ( $\geq 50 \mu \mathrm{m}$ ) were identified by using Fluo-4 fluorescence under $488 \mathrm{~nm}$ excitation and the $\mathrm{Ca}^{2+}$ signaling of the slices was continuously recorded $(1 \mathrm{~Hz})$ before, during, and after the targeted cells were stimulated with a short period $(<15 \mathrm{~s})$ of two-photon $(870 \mathrm{~nm})$ delivery. Preexperiments were used to adjust and set the energy intensity of the twophoton beam to get a point to lyse the targeted cells within 10-15 s. The $\mathrm{Ca}^{2+}$ responses in the adjacent cells were analyzed as described above.

Slice culture and nuclear migration assay. 5-Bromo-2'-deoxyuridine (BrdU) $(50 \mathrm{mg} / \mathrm{kg}$, i.p.) was administered to pregnant mice at E15. After $1 \mathrm{~h}$, embryonic brain slices $(300 \mu \mathrm{m})$ were prepared as described above. The slices were placed onto Millicell-CM culture inserts (Millipore) in six-well culture trays (Corning) with neuronal base medium containing 1\% N2, 2\% B27, 1\% Glutamax, 2.5\% HEPES buffer (1 M), and 1\% Pen/Strep (Invitrogen). Vehicle (DMSO; <0.1\%) (Haydar et al., 1999), MFA (60 $\mu \mathrm{M})$, CBX $(100 \mu \mathrm{M})$, BAPTA-AM $(50 \mu \mathrm{M})$, or indomethacin $(100 \mu \mathrm{M})$ was added to the culture medium, respectively. Slices were then incubated for $3 \mathrm{~h}$ at $37^{\circ} \mathrm{C}$ in $5 \% \mathrm{CO}_{2}$ incubator. The slices were then fixed in $4 \%$ PFA and then cryoprotected with $30 \%$ sucrose. Twenty micrometer cryosections were made and used for BrdU staining and other immunostaining.

Plasmid constructs and in utero electroporation. We used the short hairpin RNA (shRNA) Target finder at GenScript to design shRNA sequences against the mouse $\mathrm{Cx} 43$, and the shRNA fragment was inserted into the pRNAT-U6.2/Lenti vector. The targeting sequences are as follows: $\mathrm{Cx} 43$, 5'-GAAGCAGATTGAAATCAAGAA-3'. The scrambled shRNA control sequence is $5^{\prime}$-GGAATACAATAAGGAACGATA-3'. The full-length Cx43 DNA structure MC205621 is provided by Origene Technologies. To analyze the effect of Cx43 shRNA in vivo, we used in utero electroporation. We also tested the effect of another structure of $\mathrm{Cx} 43$ shRNA, MusCx43SiRNACT2 (kindly provided by Dr. E. Scemes, Albert Einstein College of Medicine, Bronx, NY) (Iacobas et al., 2008). 
A1

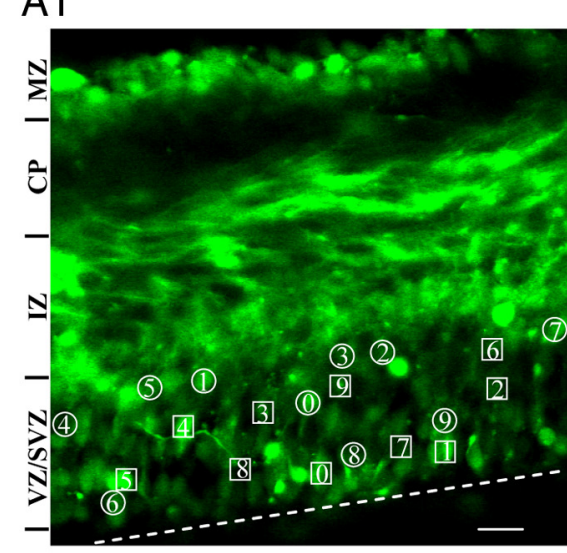

A2

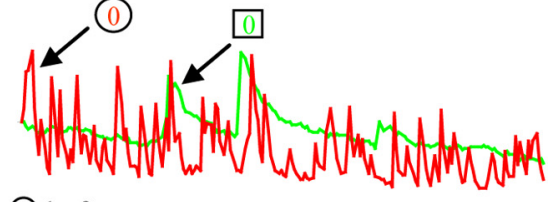

○ $1-9$

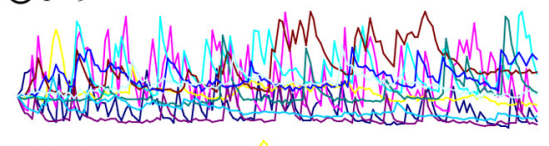

$\square 1-9$

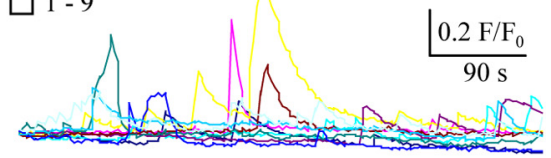

B3

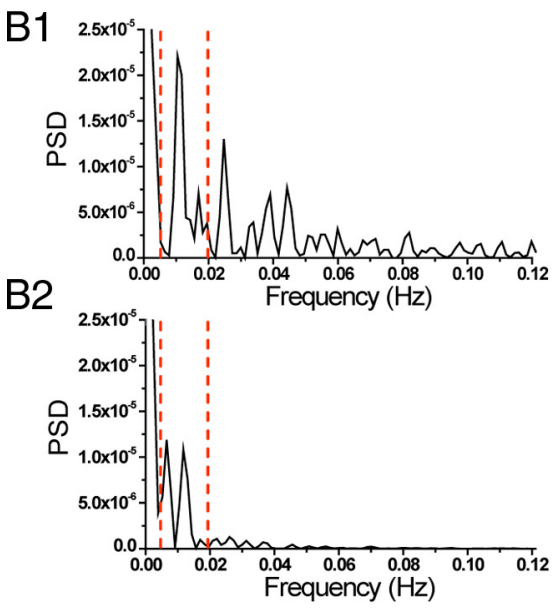

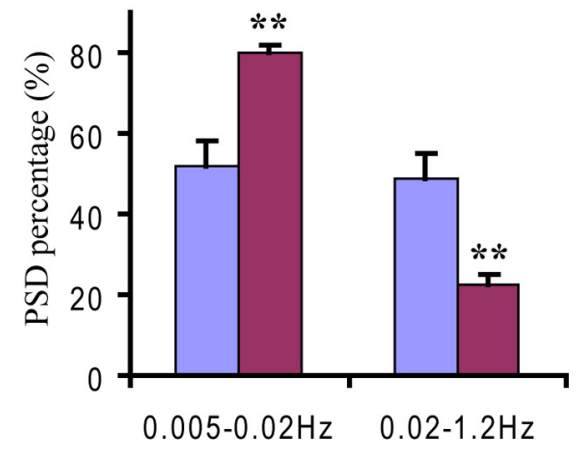

Figure 1. Neural precursors in the VZ/SVZ display dynamic spontaneous oscillatory $\mathrm{Ca}^{2+}$ transients. $\boldsymbol{A 1}$, Spontaneous $\mathrm{Ca}^{2+}$ transients were detected in VZ/SVZ cells in an acute cortical slice from the mouse embryonic brain (E15). The representative cells that display spontaneous $\mathrm{Ca}^{2+}$ transients are marked by either circles or squares numbered from 0 to 9. Scale bar, $20 \mu \mathrm{m}$. The dotted line indicates the ventricular surface. $\mathbf{A 2}$, The traces show the spontaneous $\mathrm{Ca}^{2+}$ transients in cells indicated by either circles or squares in $\mathbf{A 1}$. Two types of distinct $\mathrm{Ca}^{2+}$ oscillations can be classified in the VZ/SVZ cells. The first type shows high frequency with shorter duration (circles numbered from 0 to 9), and the second type shows lower frequency with relative longer duration (squares numbered from 0 to 9). Both types of $\mathrm{Ca}^{2+}$ oscillations were observed in the cells across the whole range of the VZ/SVZ. B, Power spectral analysis of $\mathrm{Ca}^{2+}$ signaling. The power spectra of high-frequency $\mathrm{Ca}^{2+}$ transients (B1) and low-frequency $\mathrm{Ca}^{2+}$ transients (B2) from the traces in $\boldsymbol{A 2}$ (top panel). $\mathbf{B 3}$, The percentages of power spectral density at lower $(0.005-0.02 \mathrm{~Hz})$ and higher $(0.02-1.2 \mathrm{~Hz})$ frequency bands in both the high- and low-frequency $\mathrm{Ca}^{2+}$ transients. ${ }^{* *} p<0.01 ; n=10$, respectively. Error bars indicate SEM.

Immunohistochemistry. Embryo brains (E15-E18) were fixed overnight in $4 \%$ PFA. Brains were cryostat sectioned $(20 \mu \mathrm{m})$ by microtome. The cultured embryonic neocortical slices were first fixed in 4\% PFA and then cryostat resectioned to $20 \mu \mathrm{m}$. The primary antibodies included rat monoclonal anti-BrdU (1:50; Accurate Chemical), mouse anti-neuronal class III-tubulin (Tuj-1; 1:500; Covance), phospho-histone H3 (pH3) and Ki67 (1:500, respectively; Invitrogen), rabbit anti-pcdc42 and -cdc42 (1:500, respectively; Cell Signaling Technology), and chicken anti-green fluorescent protein (GFP) (1:2000; Sigma-Aldrich).

Cell culture and Western blot analysis. N2a cell culture, protein extraction, and immunoblotting were performed using a standard protocol. The antibodies used for immunoblots are anti-Cx43 (1:200; Invitrogen), GFP (1:2000; Santa Cruz), and GAPDH (1:200; Millipore Bioscience Research Reagents). ECL plus system (GE Healthcare) was used to detect horseradish peroxidase conjugated (1:5000; Bio-Rad). Streptavidin-biotinylated HRP was used at 1:20,000 (GE Healthcare). To reprobe the membrane, Restore Western blot stripping buffer (Pierce) was used.

Statistical analysis. Statistical data are present as mean \pm SEM. Statistical analyses were performed using Student's $t$ test or $\chi^{2}$ test in appropriate experiments; a value of $p<0.05$ is considered significant.

\section{Results}

Neural precursors display dynamic $\mathrm{Ca}^{2+}$ signaling oscillation in situ

We examined the intracellular $\mathrm{Ca}^{2+}$ signals in acute embryonic brain slices in situ at near physiological condition (2 $\mathrm{mm} \mathrm{Ca}{ }^{2+}$ ACSF) and found that individual $\mathrm{Ca}^{2+}$ transients are the predominant $\mathrm{Ca}^{2+}$ fluctuations in the VZ/SVZ (Fig. $1 A$; supplemental Movie 1 , available at www.jneurosci.org as supplemental material). A distinguishing characteristic of the spontaneous $\mathrm{Ca}^{2+}$ transients is their high dynamics, which display an oscillating frequency as high as 3 peaks/min and last for the whole period of observation $(>10 \mathrm{~min})$. The $\mathrm{Ca}^{2+}$ transients randomly appear and disappear with varied duration from 4 to $20 \mathrm{~s}$. The percentage of cells showing spontaneous $\mathrm{Ca}^{2+}$ transients varies from 60 to $80 \%$ in the VZ/ SVZ cells. According to the patterns of $\mathrm{Ca}^{2+}$ transients, these cells can be classified into two groups. The cells in the first group (Fig. $1 A 1$, marked by circles with numbers) display fast repeated $\mathrm{Ca}^{2+}$ transients with short duration (Fig. 1A2, traces indicated by circles with numbers). The cells in the second group (Fig. 1A1, marked by squares with numbers) display slow frequency of $\mathrm{Ca}^{2+}$ transients with long duration (Fig. 1A2, traces indicated by squares with numbers). The mean frequencies for the fast and slow spontaneous $\mathrm{Ca}^{2+}$ transients are $16.5 \pm 4.6 / 10 \mathrm{~min}$ and $3.2 \pm 2.6 / 10 \mathrm{~min}$, respectively $(n=6$ slices), and their average durations are $14.0 \pm 1.4$ and $31.1 \pm 3.6$ s, respectively ( $n=6$ slices). To our knowledge, these dynamic $\mathrm{Ca}^{2+}$ transients have not been described in the embryonic VZ/SVZ cells.

As shown in Figure 1 $A 1$, both types of $\mathrm{Ca}^{2+}$ transients occur in cells across the whole range of the VZ. However, careful examination revealed that there are more cells in the upper strata of the VZ that show fast spontaneous $\mathrm{Ca}^{2+}$ transients than in the lower strata of the VZ (Fig. $1 \mathrm{Al}$; supplemental Movie 1, available at www.jneurosci.org as supplemental material). To identify the properties of these $\mathrm{Ca}^{2+}$ transients in frequency domain, we used power spectrum analysis to analyze the high- and low-frequency $\mathrm{Ca}^{2+}$ transients. As expected, the high-frequency $\mathrm{Ca}^{2+}$ transients display peaks of power spectrum extending to relatively higher frequency (Fig. 1B1), whereas the peaks of power spectrum of low-frequency $\mathrm{Ca}^{2+}$ transients usually locate $<0.02 \mathrm{~Hz}$ (Fig. $1 \mathrm{B2})$. The percentages of power spectral density at lower $(0.005-$ $0.02 \mathrm{~Hz})$ and higher $(0.02-1.2 \mathrm{~Hz})$ frequency bands in both the high- and low-frequency $\mathrm{Ca}^{2+}$ transients were quantified in Figure $1 B 3$ (52.13 \pm 6.22 vs $79.89 \pm 2.13, p<0.01$; and $48.95 \pm 6.05$ vs $22.59 \pm 2.46, p<0.01 ; n=10$, respectively), which demonstrates the difference of distribution of power spectrum between the high- and low-frequency $\mathrm{Ca}^{2+}$ transients. Interestingly, the power spectra of both high- and low-frequency $\mathrm{Ca}^{2+}$ transients 
did not display multiple harmonic peaks, suggesting the chaotic property of these $\mathrm{Ca}^{2+}$ transients.

Although $\mathrm{Ca}^{2+}$ waves were previously reported to exist in rat embryonic cerebrum in $0 \mathrm{mM} \mathrm{Ca}^{2+}$ ACSF (Weissman et al., 2004), we have rarely observed such cohort spontaneous $\mathrm{Ca}^{2+}$ waves in the mouse embryonic VZ/SVZ under our experimental conditions $\left(2 \mathrm{mM} \mathrm{Ca}^{2+}\right.$ ACSF; only one $\mathrm{Ca}^{2+}$ wave was observed in the total 126 trials). However, $\mathrm{Ca}^{2+}$ waves are always evoked by electrical focal stimulation as well as single-cell two-photon stimulation (see below) in our experiment, which is consistent with the previous reports (Weissman et al., 2004; Liu et al., 2006).

\section{$\mathrm{Ca}^{2+}$ transients in neural precursors depend on functional gap junctions/hemichannels}

To demonstrate the existence of functional gap junction in the embryonic VZ/ SVZ cells, we first examined the electrical coupling in the mouse VZ cells at E16 using whole-cell patch-clamp recordings. When step voltages $(-120$ to $100 \mathrm{mV})$ were applied, $26 \%$ of the recorded cells display passive currents (Fig. 2A1) and lower input resistance $\left(R_{\mathrm{IN}}, 343 \pm 92\right.$ $\mathrm{M} \Omega ; n=12)$ with a mean resting membrane potential $\left(V_{\mathrm{R}}\right)$ of $-76 \pm 6 \mathrm{mV}(n=$ $12)$, suggesting that these cells are coupled via gap junctions (LoTurco and Kriegstein, 1991). In contrast, other cells showed higher $R_{\mathrm{IN}}(1-3 \mathrm{G} \Omega$ ) with relatively lower $V_{\mathrm{R}}(-40$ to $-60 \mathrm{mV})$. Approximately $60 \%$ of the recorded cells with low $R_{\mathrm{IN}}$ were radial glia, which can be recognized by their morphology after filling with Lucifer yellow. More detailed analysis of the biophysical property of the VZ cells further suggests that these cells display variability in their $V_{\mathrm{R}}$ and $R_{\mathrm{IN}}$. A plot of $R_{\mathrm{IN}}$ as a function of $V_{\mathrm{R}}$ illustrates a slight correlation between $R_{\mathrm{IN}}$ and $V_{\mathrm{R}}(r=0.594)$ (supplemental Fig. S2A, available at www. jneurosci.org as supplemental material). The VZ cells could be separated into two groups based on their $R_{\mathrm{IN}}$ as illustrated in supplemental Figure S2 B (available at www.jneurosci.org as supplemental material). MFA had been used to block gap junctions/ hemichannels in the embryonic neocortex (Weissman et al., 2004) and retina (Pearson et al., 2005) and was not accompanied by changes of intracellular calcium, $\mathrm{pH}$, protein kinase $\mathrm{C}$ activity (Harks et al., 2001). Furthermore, we showed that the purinergic signaling cascade was intact in glioma cells treated with gap junction blockers (supplemental Fig. S1 B, available at www.jneurosci. org as supplemental material). We then checked the effect of MFA $(100 \mu \mathrm{M})$ on gap junction coupling currents in the VZ/SVZ precursors. As shown in Figure 2, $A 1$ and $A 2$, the passive currents were significantly reduced by MFA $(100 \mu \mathrm{M})$ and the $R_{\mathrm{IN}}$ was increased to the level of the uncoupled cells $(1.8 \pm 0.3 \mathrm{G} \Omega ; n=7)$. After washout, the passive current was completely recovered. The
$\mathrm{A} 2$
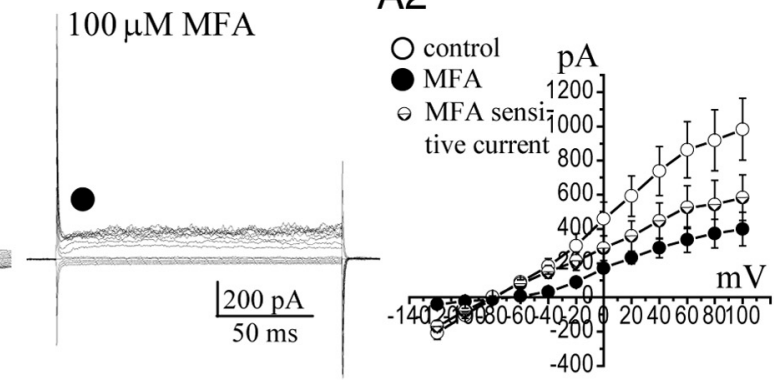

$100 \mu \mathrm{M}$ MFA

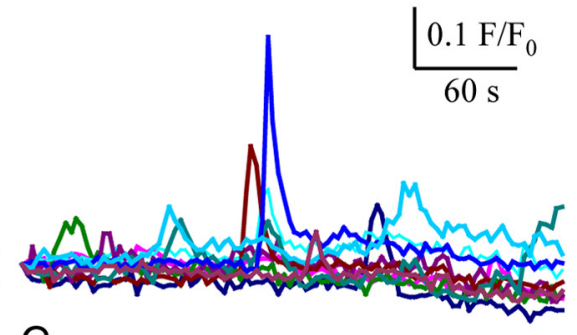

C
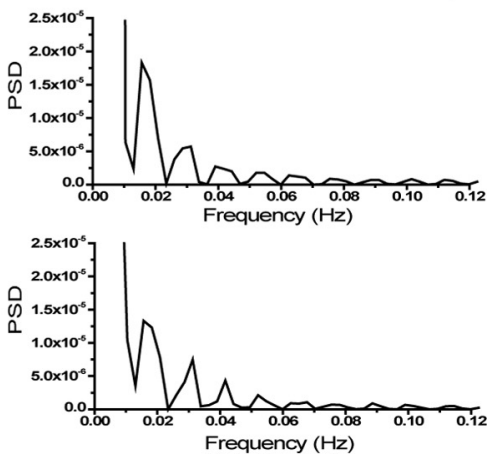

Figure 2. Spontaneous $\mathrm{Ca}^{2+}$ transients depend on functional gap junctions/hemichannels in the VZ/SVZ. A, Whole-cell patch-clamp recording in the VZ cells. A1, Passive currents were observed in a VZ cell, when step voltages (from -120 to $100 \mathrm{mV}$ ) were applied. The passive currents were reduced by application of gap junction blocker MFA $(100 \mu \mathrm{M}) . \mathbf{A 2}, I-V$ curves show the passive currents in contro ), and the MFA-sensitive currents $(\ominus)$. The MFA-sensitive current reverses at $-78 \mathrm{mV}$. B1, Traces show

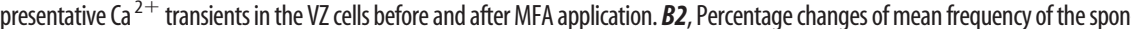

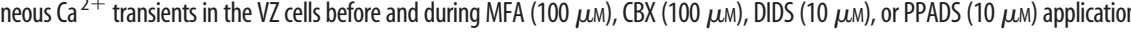
$\left({ }^{* *} p<0.01 ; n=4,4,4,5\right.$, respectively). Error bars indicate SEM. C, Power spectra of spontaneous $\mathrm{Ca}^{2+}$ transients in two representative cells in $\boldsymbol{B} 1$ after blocking gap junctions/hemichannels with MFA. Note the regular harmonic peaks.

MFA-sensitive current reverses near the $V_{\mathrm{R}}$ of the recorded cells (Fig. 2A2), which further suggests that they are mediated by gap junction coupling (Liu et al., 2006).

As a next step, we tested whether functional gap junctions/ hemichannels are involved in the spontaneous $\mathrm{Ca}^{2+}$ signal oscillation in the embryonic VZ/SVZ precursors. We found that the spontaneous $\mathrm{Ca}^{2+}$ transients were significantly reduced after blocking gap junctions/hemichannels with MFA (Fig. 2B1). Their mean frequency was reduced to $20 \pm 7.7 \%(p<0.01 ; n=$ 4) (Fig. 2 B2). Similar results were observed with another type of gap junction blocker, CBX $(100 \mu \mathrm{M})$, the frequency of $\mathrm{Ca}^{2+}$ transients was reduced to $19.1 \pm 4.6 \%(p<0.01 ; n=4)$ (Fig. 2B2). We then analyzed the power spectrum of these remaining $\mathrm{Ca}^{2+}$ transients. Surprisingly, the power spectra usually display harmonic peaks with a dominant frequency at $\sim 0.015 \mathrm{~Hz}$ (Fig. 2C). These results suggest that gap junctions/hemichannels not only provide cues for the occurrence of dynamic $\mathrm{Ca}^{2+}$ transients in the VZ/SVZ but also disturb the intrinsic harmonic $\mathrm{Ca}^{2+}$ signal- 


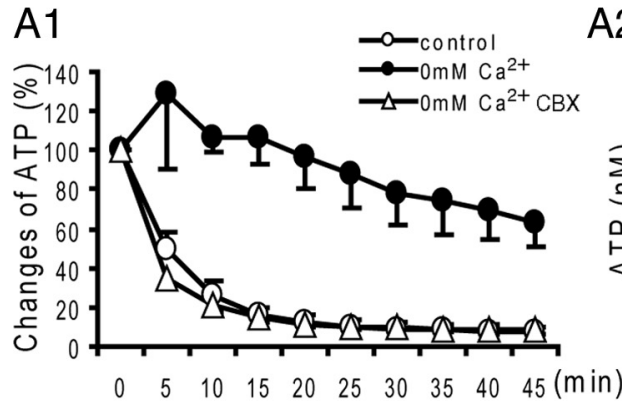

B1

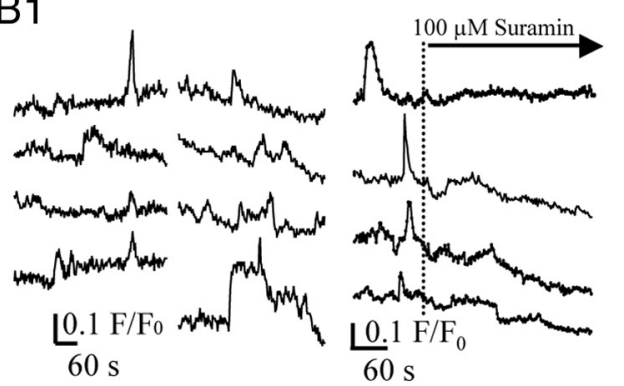

B2

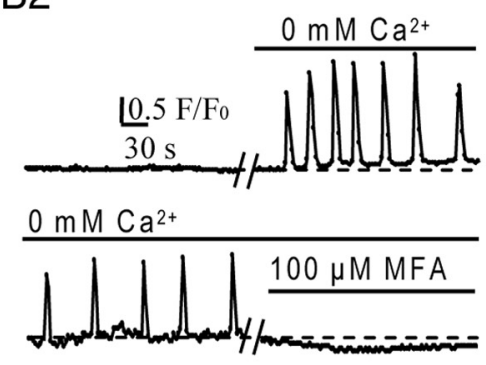

$\mathrm{C} 1$

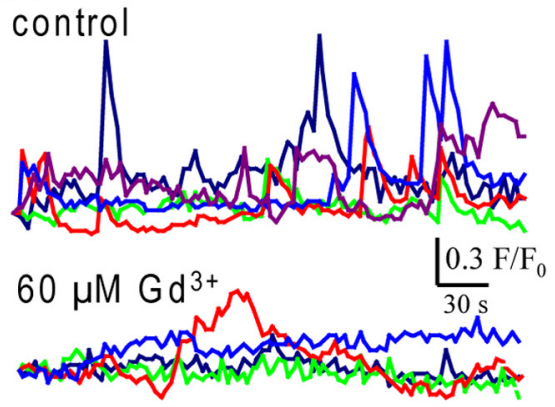

$100 \mu \mathrm{M} \mathrm{La}^{3+}$
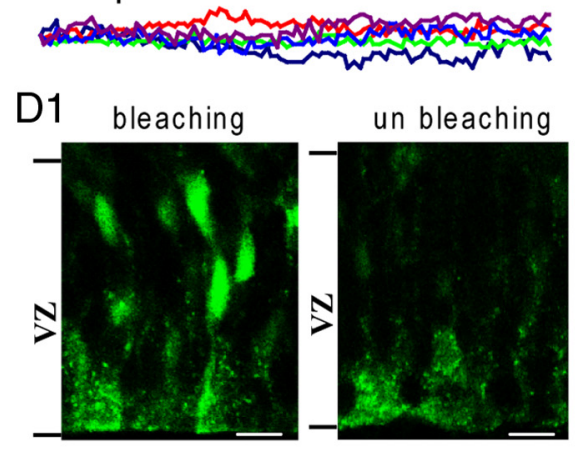

$\mathrm{C} 2$

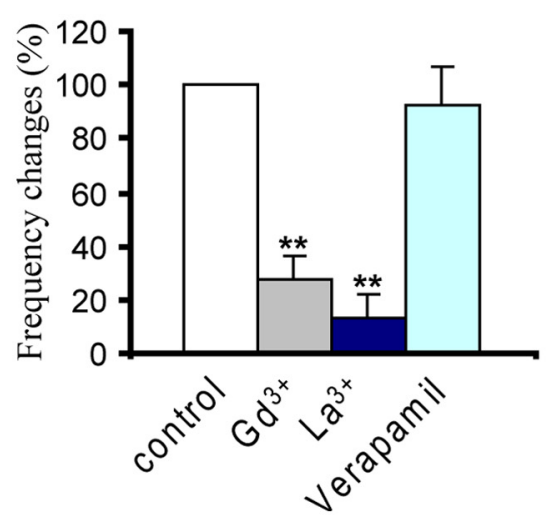

D2

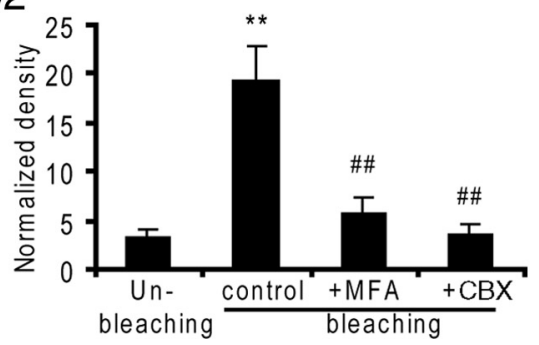

Figure 3. ATP is released via functional gap junctions/hemichannels in the VZ precursors. A1, ATP release curves in the slices perfused with the control (ACSF) $(\bigcirc), 0 \mathrm{~mm} \mathrm{Ca}^{2+}(0)$, and $0 \mathrm{~mm} \mathrm{Ca}^{2+}$ plus CBX $(100 \mu \mathrm{m})(\triangle)$ perfusate. In the control perfusate, ATP release was decreased with first-order exponential decay $\left(t_{1 / 2}=6.3 \mathrm{~min}\right)$. The $0 \mathrm{mM} \mathrm{Ca}^{2+}$ perfusion induced significant increase in ATP release and prolonged the $t_{1 / 2}$ to $36.3 \mathrm{~min}$. Gap junction blocker CBX totally abolished $0 \mathrm{~mm} \mathrm{Ca}{ }^{2+}$-induced ATP release. A2, The remaining concentration of ATP in the control, $0 \mathrm{~mm} \mathrm{Ca}^{2+}$, and $0 \mathrm{~mm} \mathrm{Ca}^{2+}$ plus CBX perfusate after 45 min perfusion. ${ }^{* *} p<0.01, n=6$, vs control. ${ }^{\# \#} p<0.01, n=6$, vs $0 \mathrm{~mm} \mathrm{Ca}^{2+} . \boldsymbol{B}, \mathrm{GL} 261$ cells loaded with $\mathrm{Ca}^{2+}$ indicator Fluor-4 were gently overlaid onto the surface of the embryonic cortical slices. B1, Small spontaneous $\mathrm{Ca}^{2+}$ transients were detected in $\mathrm{GL} 261$ cells at the region corresponding to the VZ/SVZ. Suramin application abolished the spontaneous $\mathrm{Ca}^{2+}$ transients in GL261 cells. B2, In a silent GL261 cell overlaid onto the region of the VZ/SVZ, $0 \mathrm{~mm} \mathrm{Ca}^{2+} \mathrm{ACSF}$ perfusion induced spontaneous $\mathrm{Ca}^{2+}$ transients. Gap junctions/hemichannels blocker MFA $(100 \mu \mathrm{M})$ abolished $0 \mathrm{~mm} \mathrm{Ca}^{2+}$ ACSF-induced $\mathrm{Ca}^{2+}$ transients. C1, Profiles of spontaneous $\mathrm{Ca}^{2+}$ transients in the VZ precursors before and during hemichannel blocker $\mathrm{Gd}^{3+}$ or $\mathrm{La}^{3+}$ application. C2, Percentage changes of the mean frequency of the spontaneous $\mathrm{Ca}^{2+}$ transients in the VZ cells before and during $\mathrm{Gd}^{3+}(60 \mu \mathrm{M}), \mathrm{La}^{3+}(100 \mu \mathrm{M})$, or verapamil $\left(10 \mu \mathrm{M}\right.$ ) application $\left({ }^{* *} p<0.01 ; n=8,6,8,4\right.$, respectively). $\boldsymbol{D}$, Embryonic brain slices were loaded with $\mathrm{Ca}^{2+}$ caged agent (NP-EGTA; $5 \mu \mathrm{m}$ ) and elevated intracellular $\mathrm{Ca}^{2+}$ induces Lucifer yellow uptake in the VZ cells. D1, In the UV bleached hemisphere, Lucifer yellow-positive cells were detected and mainly locate at the upper portion of the VZ. In the unbleached hemisphere, no apparent Lucifer yellow-positive cells were detected. Scale bars, $10 \mu \mathrm{m}$. D2, Normalized fluorescence intensity of Lucifer yellow uptake cells in slices treated with unbleaching, bleaching, bleaching plus MFA (100 $\mu \mathrm{M})$, and bleaching plus CBX $(100 \mu \mathrm{M}) .{ }^{* *} p<0.01$ vs unbleaching, $n=11 .{ }^{\# \#} p<0.01$ vs bleaching, $n=13$ and 9 , respectively. Error bars indicate SEM. ing oscillations into an irregular chaotic condition, which might contribute to the biological behaviors of the VZ precursors.

Gap junction/hemichannel blockers may also affect the anion channels and P2X receptor channels (Spray et al., 2006). We, therefore, tested the effect of anion channel blocker DIDS (Eskandari et al., 2002) and P2X receptor blocker PPADS (Zhao, 2005). As shown in Figure 2B2, neither DIDS (10 $\mu \mathrm{M} ; n=5)$ nor iso$\operatorname{PPADS}(50 \mu \mathrm{M} ; n=6)$ has an effect on the spontaneous $\mathrm{Ca}^{2+}$ transients in the $\mathrm{VZ}$ precursors. Together, our results suggest that functional gap junctions/hemichannels are prerequisites for the dynamic spontaneous $\mathrm{Ca}^{2+}$ oscillations in the neural precursors of the VZ/SVZ.

Neural precursors release ATP

via hemichannels

VZ precursors express $\mathrm{P}_{2} \mathrm{Y}_{1}$ receptors and display $\mathrm{Ca}^{2+}$ increase in response to extracellular ATP (Weissman et al., 2004; Liu et al., 2008). In addition, we found that a low concentration of extracellular ATP induces $\mathrm{Ca}^{2+}$ oscillation in cultured glioma cells (data not shown). To provide direct evidence for ATP release in the embryonic cerebrum, we detected the ATP in the perfusate using bioluminescence assay (Lazarowski et al., 2000; De Vuyst et al., 2006) (supplemental Fig. S1 $A$, available at www.jneurosci.org as supplemental material). ATP release from the embryonic neocortical slice in control perfusate (2 $\mathrm{mM} \mathrm{Ca}{ }^{2+}$ ASCF) was decreased with firstorder exponential decay (Fig. 3A1), which is similar to ATP release from cultured astrocytes via gap junctions/hemichannels (Lazarowski et al., 2000). The decay halftime $\left(t_{1 / 2}\right)$ is $6.3 \mathrm{~min}$ and the remaining ATP concentration after 45 min perfusion is $0.06 \pm 0.01 \mathrm{~nm}$. Opening the hemichannel by reducing extracellular $\mathrm{Ca}^{2+}\left(0 \mathrm{~mm} \mathrm{Ca}{ }^{2+} \mathrm{ACSF}\right)$, which has been routinely used in cultured cells as well as in acute slices (Weissman et al., 2004; De Vuyst et al., 2006), significantly increased ATP release in the perfusate (Fig. $3 A 1, A 2)$. The $t_{1 / 2}$ is prolonged to $36.3 \min (p<0.01 ; n=6)$ and the remaining ATP concentration is increased to $0.29 \pm 0.02 \mathrm{nM}(p<0.01 ; n=6)$. We further tested whether blocking of gap junctions/hemichannels could affect the ATP release. As expected, blocking gap junctions/hemichannels with CBX (100 $\mu \mathrm{M})$ reduced the ATP release induced by $0 \mathrm{mM} \mathrm{Ca}^{2+}\left(t_{1 / 2}=4.2 \mathrm{~min} ; p<0.01\right.$; remaining concentration, $0.12 \pm 0.01 \mathrm{nM}$; $p<0.01 ; n=6$ ) (Fig. 3A1,A2). Similar results were observed with another gap 
junction blocker, 18- $\alpha$-glycerrhetinic acid $\left(t_{1 / 2}=3.7 \mathrm{~min} ; p<0.01\right)$.

To examine the existence of spontaneous ATP release in the VZ precursors, we used a biodetection technique using glioma cells (GL261) (Haas et al., 2006). At low cell density, the GL261 cells showed no obvious spontaneous $\mathrm{Ca}^{2+}$ transients but responded to ATP at the nanomolar level (supplemental Fig. S1 B, C, available at www.jneurosci.org as supplemental material). We then overlaid the GL261 cells onto the surface of embryonic brain slices (E16) and checked the $\mathrm{Ca}^{2+}$ signaling in these GL261 cells locating at the VZ. As expected, small spontaneous $\mathrm{Ca}^{2+}$ transients were detected in those cells in 4 of 10 of the slices tested (Fig. 3B1). The mean frequency of the $\mathrm{Ca}^{2+}$ transients was $1.2 \pm 0.1$ peaks $/ 10 \min (n=12)$, and the mean amplitude was $0.17 \pm 0.07(F /$ $\left.F_{0} ; n=11\right)$. These $\mathrm{Ca}^{2+}$ transients showed varied rise time from 10 to $30 \mathrm{~s}$, and a mean duration of $74.9 \pm 10.1 \mathrm{~s}(n=$ 10). As shown in Figure 3C1, application of P2Y receptor blocker suramin $(100 \mu \mathrm{M})$ significantly reduced the spontaneous $\mathrm{Ca}^{2+}$ transients (mean frequency, $0.17 \pm$ 0.4 peaks $/ 10 \mathrm{~min} ; p<0.01 ; n=12$ ). For the slices that showed no spontaneous $\mathrm{Ca}^{2+}$ transients in the GL261 cells, we induced ATP release by perfusion with $0 \mathrm{mM}$ $\mathrm{Ca}^{2+}$ ACSF. As shown in Figure 3B2, the silent GL261 cell began to show $\mathrm{Ca}^{2+}$ transients and the basal line was elevated. Blocking gap junctions/hemichannels with MFA $(100 \mu \mathrm{M})$ completely abolished these $\mathrm{Ca}^{2+}$ transients and reduced the basal line (Fig. 3B2). As a control, we did not observe similar $\mathrm{Ca}^{2+}$ transients in GL261 cells alone in $0 \mathrm{~mm} \mathrm{Ca}{ }^{2+}$ ACSF (supplemental Fig. S1 B, available at www.jneurosci.org as supplemental material).

To demonstrate the involvement of hemichannel-mediated ATP release in the occurrence of $\mathrm{Ca}^{2+}$ signal oscillation in the $\mathrm{VZ}$ precursors, we tested the effects of $\mathrm{La}^{3+}$ and $\mathrm{Gd}^{3+}$, both of which block the hemichannels but have no effect on gap junctions (Contreras et al., 2002; Stout et al., 2002). The $\mathrm{Ca}^{2+}$ transients were significantly reduced in the neural precursors after $\mathrm{La}^{3+}$ $(100 \mu \mathrm{M})$ or $\mathrm{Gd}^{3+}(60 \mu \mathrm{M})$ application (Fig. 3C1,C2). ATP may also be released via the transporter system (Pangrsic et al., 2007). We then tested the effect of ATP-binding cassette transporter inhibitor verapamil $(10 \mu \mathrm{M})(Z h a o, 2005)$, which showed no effect on the spontaneous $\mathrm{Ca}^{2+}$ oscillation in the $\mathrm{VZ}$ precursors (Fig. 3C2). Together, our results indicate that hemichannelmediated ATP release plays a major role in the occurrence of $\mathrm{Ca}^{2+}$ signaling in the VZ precursors.

It has been shown that intracellular $\mathrm{Ca}^{2+}$ increase triggers the hemichannel opening in cultured cells (De Vuyst et al., 2006). Thus, we tested whether elevating intracellular $\mathrm{Ca}^{2+}$ could induce hemichannel opening in the VZ/SVZ cells. Embryonic cortical slices were first loaded with $\mathrm{Ca}^{2+}$ caging agent $(5 \mu \mathrm{M}$ NP-EGTA AM) and then one hemisphere was subjected to UV
A2

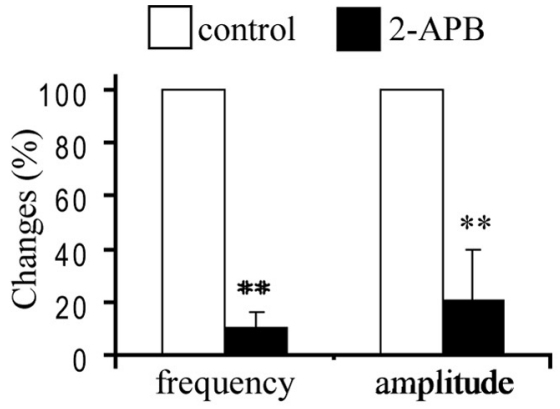

B2

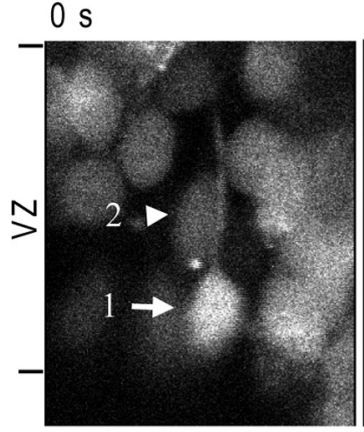

$10 \mathrm{~s}$
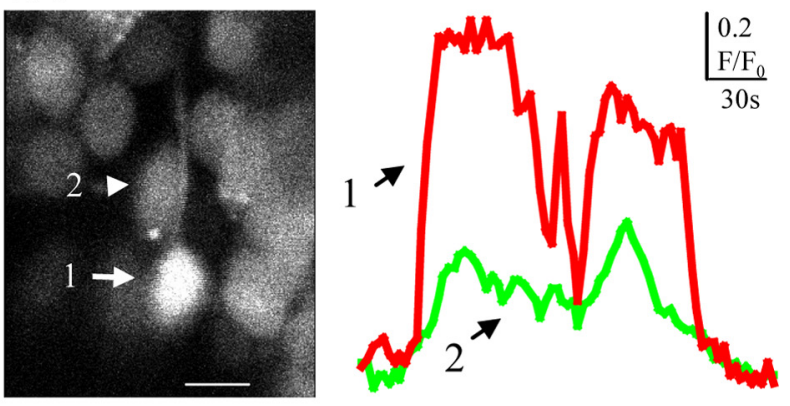

B3

Figure 4. $\mathrm{Ca}^{2+}$ signal transfer among the VZ precursors. A1, Profile of spontaneous $\mathrm{Ca}^{2+}$ transients in the VZ/SVZ cells before and during the $\mathrm{IP}_{3}$ receptor blocker 2-APB application. $\mathbf{A 2}$, Changes of mean frequency and amplitude of spontaneous $\mathrm{Ca}^{2+}$ transients in VZ

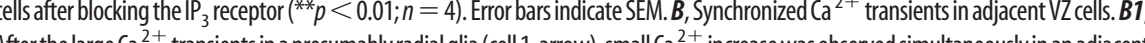
cell (cell 2, arrowhead) in the VZ. The ventricular surface is at the bottom of the images. Scale bar, $10 \mu \mathrm{m}$. B2, Traces show the Ca ${ }^{2+}$ transients in the cells indicated by the corresponding numbers in B1. B3, Another two typical pair of synchronized $\mathrm{Ca}^{2+}$ transients in adjacent VZ precursors. The open and solid triangles indicate the nonsynchronized and synchronized $\mathrm{Ca}^{2+}$ transients, respectively. bleaching in HEPES perfusate containing Lucifer yellow (5 mg/ $\mathrm{ml}$ ). As shown in Figure 3D1, Lucifer yellow-positive cells were detected in the bleached hemisphere, which are predominantly located at the upper (superficial) strata of the VZ. In contrast, very few Lucifer yellow-positive cells were detected in the unbleached hemisphere. To demonstrate that the Lucifer yellow uptake is mediated by gap junctions/hemichannels, MFA (100 $\mu \mathrm{M})$ was included in HEPES perfusate during bleaching. As expected, the uptake of Lucifer yellow was significantly reduced (Fig. 3B2). Similar results were also observed with CBX (100 $\mu \mathrm{M})$ (Fig. 3D2). Our results provide evidence that intracellular $\mathrm{Ca}^{2+}$ transients might trigger the opening of hemichannels, which reveals a regenerating mechanism for $\mathrm{Ca}^{2+}$ signal oscillations in the VZ precursors.

\section{Gap junctions/hemichannels control the $\mathrm{Ca}^{2+}$ signal propagation in the $\mathrm{VZ}$}

Previous work has shown that $\mathrm{Ca}^{2+}$ signaling in the embryonic cortical cells mainly depends on intracellular $\mathrm{Ca}^{2+}$ release from the endoplasmic reticulum (ER) (Owens and Kriegstein, 1998). We tested whether the $\mathrm{Ca}^{2+}$-mobilizing messenger $\mathrm{IP}_{3}$ is involved in the spontaneous $\mathrm{Ca}^{2+}$ oscillation in the $\mathrm{VZ}$ precursors. As shown in Figure $4 A$, blocking the $\mathrm{IP}_{3}$ receptor with 2-APB 

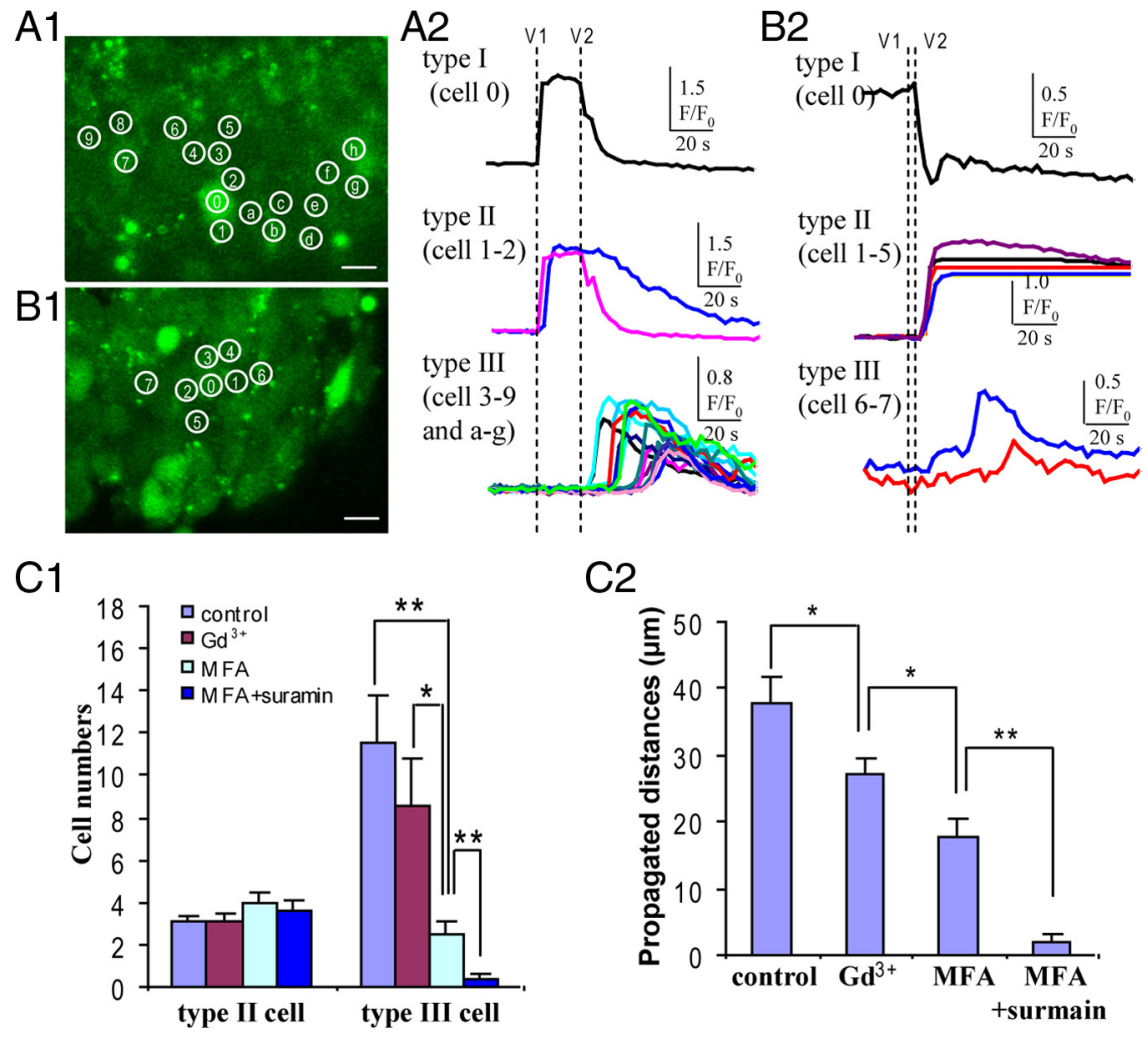

\section{C2}

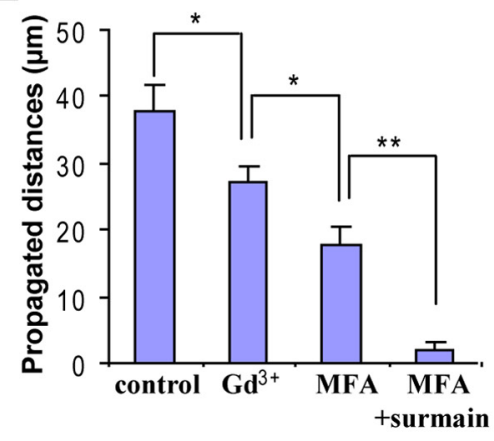

Figure 5. $\mathrm{Ca}^{2+}$ signaling propagation among the VZ precursors. $\boldsymbol{A 1}$, Two-photon single-cell stimulation induced $\mathrm{Ca}^{2+}$ signaling propagation in the VZ. The stimulated cell (type I cell) is marked as number 0 . The first-order cells (type II cells) are marked as numbers 1 and 2 . The propagated cells are marked as numbers $3-9$ and a to $\mathrm{g}$. Scale bar, $10 \mu \mathrm{m}$. $\mathbf{A 2}$, The $\mathrm{Ca}^{2+}$ responses and their propagation from the stimulated cells to the first-order cells and the propagated cells. B1, Two-photon single-cell stimulation induced $\mathrm{Ca}^{2+}$ signaling propagation in the VZ in the presence of MFA. The stimulated cell (type I cell) is marked as number 0 . The first-order cells (type II cells) are marked as numbers $1-5$. The propagated cells are marked as numbers 6 and 7. B2, The $\mathrm{Ca}^{2+}$ signaling responses and their propagation from the stimulated cells to the first-order cells and the propagated cells in the presence of MFA. C1, The changes of the mean number of the first-order cells and the propagated cells in control and in the presence of $\mathrm{Gd}^{3+}$, MFA, and MFA plus suramin. ${ }^{*} p<0.05,{ }^{* *} p<0.01 ; n=19,13,8$, and 9 , respectively. $\mathbf{C 2}_{2}$, The changes of the maximum propagated distance in control and in the presence of $\mathrm{Gd}^{3+}, \mathrm{MFA}$, and MFA plus suramin. ${ }^{*} p<0.05,{ }^{* *} p<0.01 ; n=19,13,8$, and 9, respectively. Error bars indicate SEM.

$(100 \mu \mathrm{M})$ abolished the $\mathrm{Ca}^{2+}$ transients, which suggests that $\mathrm{IP}_{3}$ is the major $\mathrm{Ca}^{2+}$-mobilizing messenger responsible for the $\mathrm{Ca}^{2+}$ oscillation in the VZ precursors.

Although $\mathrm{IP}_{3}$ diffusion via gap junction has been reported in cultured cells (Finkbeiner, 1992) as well as in the Corti organ (Anselmi et al., 2008), it is not clear that it plays a role in the occurrence of $\mathrm{Ca}^{2+}$ signaling in the cortical VZ precursors. Therefore, we examined the synchronized pairs of $\mathrm{Ca}^{2+}$ transients in adjacent VZ cells in situ (Fig. 4B). After the $\mathrm{Ca}^{2+}$ transients in the presumable radial glia, simultaneous $\mathrm{Ca}^{2+}$ transients occurred in the adjacent cell (Fig. 4 B1,B2). Unlike the propagated $\mathrm{Ca}^{2+}$ waves involving multiple cells, the synchronized $\mathrm{Ca}^{2+}$ transients occurred only in the adjacent cells with little phase delay (Fig. $4 B 3$ ), indicating the existence of direct $\mathrm{Ca}^{2+}$-mobilizing messenger transfer among the $\mathrm{VZ}$ precursors.

To dissect the mechanism for $\mathrm{Ca}^{2+}$ signaling propagation in the VZ precursors, we induced ATP release from one single cell by using two-photon stimulation. The typical $\mathrm{Ca}^{2+}$ signaling propagation in the VZ/SVZ is shown in Figure $5 A$ (for the movie, see supplemental Movie $2 a$, available at www.jneurosci.org as supplemental material). Three types of cells can be identified. Type I cell is the stimulated cell characterized with $\mathrm{Ca}^{2+}$ increase and decrease, which indicate the lysis of the cell and will be the initial major source of ATP. Type II cells are cells directly adjacent to the stimulated type I cell, also called firstorder cells (Anselmi et al., 2008). The $\mathrm{Ca}^{2+}$ responses in these cells could be caused by the ATP released from the type I cell. Type III cells, also called the propagated cells, represent the $\mathrm{Ca}^{2+}$ signaling propagation in the VZ (Fig. 5A1,A2). The mean values for the first order cells, the propagated cells, and the maximum propagation distance in control are $3.1 \pm 0.3$ cells, $11.5 \pm 3.3$ cells, and $46.7 \pm 4.58 \mu \mathrm{m}$, respectively $(n=19)$ (Fig. 5C1,C2). After blocking both gap junction and hemichannel, the remaining $\mathrm{Ca}^{2+}$ signaling propagation would represent the extracellular diffusion of ATP released from the stimulated cell. We first tested the effect of blocking gap junctions/hemichannels with MFA. We found that the numbers of the propagated cells and the maximum propagated distance were significantly reduced $(2.5 \pm 0.6$ cells and $17.7 \pm 2.8 \mu \mathrm{m}$; $n=8$, respectively), whereas the numbers of the first-order cells showed no significant changes (Fig. 5C1) (for the movie, see supplemental Movie $2 b$, available at www. jneurosci.org as supplemental material). After coblocking of the $\mathrm{P} 2 \mathrm{Y}$ receptor with suramin, the mean values for the propagated cell numbers and the maximum propagated distance were further reduced to $0.3 \pm 0.3$ cells and $1.9 \pm 1.3 \mu \mathrm{m}(n=9$, respectively) (Fig. 5C1,C2). In addition, our previous work had shown that suramin alone abolished focal stimulation-evoked $\mathrm{Ca}^{2+}$ wave propagation in the VZ precursors (Liu et al., 2008). These results suggest that extracellular ATP diffusion can induce $\mathrm{Ca}^{2+}$ responses in the adjacent cells but could not account for the whole distance of $\mathrm{Ca}^{2+}$ signal propagation in the VZ. We further dissected the role of functional hemichannels in $\mathrm{Ca}^{2+}$ signal propagation. As shown in Figure 5, C1 and C2, selective blocking of the hemichannels with $\mathrm{Gd}^{3+}(100 \mu \mathrm{M})$ significantly reduced the maximum propagated distance, but the numbers of the propagated cells and the maximum propagated distance are still higher than those altered by gap junctions/hemichannel blocker MFA. Together, our results suggest that $\mathrm{Ca}^{2+}$ signaling propagation depends on functional gap junctions/ hemichannels via both extracellular ATP release and intracellular $\mathrm{Ca}^{2+}$-mobilizing messenger diffusion in the neural precursors in the VZ.

\section{Apically directed interkinetic nuclear migration requires functional gap junctions/hemichannels}

To identify the role of functional gap junctions/hemichannels in interkinetic nuclear migration, the nuclei of the VZ cells were labeled with Hoechst and their movement was observed in situ by time-lapse live imaging. In the control ACSF, a large number of VZ cells displayed dynamic nuclear motility characterized with multiple directional movements, which were indicated by a red cross in Figure 6A1. The cells showing nuclear motility accounts for $61 \%$ of the total cells in the VZ/SVZ (1340 VZ/SVZ cells in six 
slices observed in $10 \mathrm{~min}$ ) (Fig. 6A2). After blocking gap junctions/hemichannels with MFA $(100 \mu \mathrm{M})$, the nuclear motility was gradually reduced and most of them became "frozen" (Fig. 6A2). The percentage of VZ/SVZ cells showing nuclear motility was reduced to $6.7 \%$ (1241 cells in six slices; $p<0.01$ ) (Fig. 6A2). We further examined whether the nuclear motility depends on the intracellular $\mathrm{Ca}^{2+}$ signaling. After incubation with cell-permeable $\mathrm{Ca}^{2+}$ chelator BAPTA-AM (50 $\left.\mu \mathrm{M}\right)$ for 30 $\mathrm{min}$, the percentage of cells displaying nuclear motility was reduced to $13.7 \%$ (727 cells in three slices; $p<0.01$ ) (Fig. 6A2).

We then extended the time-lapse recording time, so that we could analyze the interkinetic nuclear migration. In the control slices, the neural precursors displayed both up and down nuclear migration along the radial axis. However, the nuclear translocation toward the ventricular surface is more frequent and faster, suggesting that the apically directed migration is a more dynamic process. Figure $6 B$ shows the representative migration of a nucleus to the ventricular surface. As indicated by the dashed outline, the nuclear shape becomes elongated radially during the migration, suggesting that the nucleus is pulled down by the associated microtubules. We further detected the nuclear migration before and after blocking gap junctions/hemichannels. In Figure 6C1, the arrows show the nuclear migrations in the VZ. The heads of arrows indicate the direction of nuclear movement, and their lengths indicate the translocated distances during $60 \mathrm{~min}$. Five nuclei with the fastest translocations were selected for statistics, which gives an average translocation distance of $15.2 \mu \mathrm{m}$ and an average translocation speed of $1.8 \mu \mathrm{m} / \mathrm{min}(n=$ 4 slices) (Fig. 6C2). After blocking gap junctions/hemichannels with MFA, the nuclear migration was inhibited and the average translocation distance and speed of five nuclei with the fastest translocations were reduced to $6.6 \pm 2.3 \mu \mathrm{m}$ and $0.9 \pm 0.4 \mu \mathrm{m} /$ min, respectively ( $n=3$ slices) (Fig. 6C2). Furthermore, we found that, after abolishing the intracellular $\mathrm{Ca}^{2+}$ with BAPTA-AM $(50 \mu \mathrm{M})$, the interkinetic nuclear translocation was also significantly reduced (translocation distance, $6.56 \pm 2.1 \mu \mathrm{m}$; speed, $0.87 \pm 0.36 \mu \mathrm{m} / \mathrm{min} ; n=3$, respectively)

(Fig. 6C2). Thus, functional gap junctions/hemichannels may affect the interkinetic nuclear migration via intracellular $\mathrm{Ca}^{2+}$ signaling in the neural precursors in the VZ.

The role of functional gap junctions/hemichannels in interkinetic nuclear migration was further tested in cultured slices. We first detected the interkinetic nuclear migration in the VZ precur-
A1

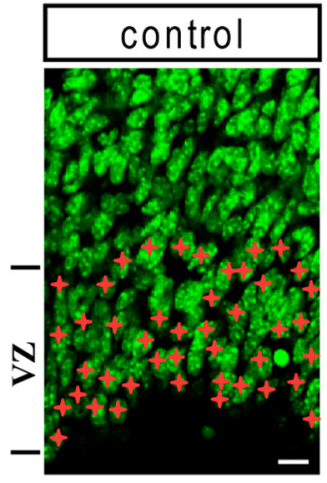

B
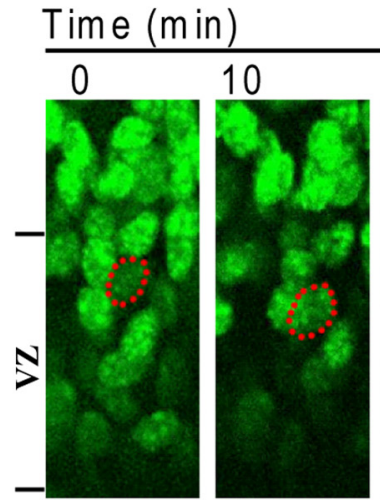

A2
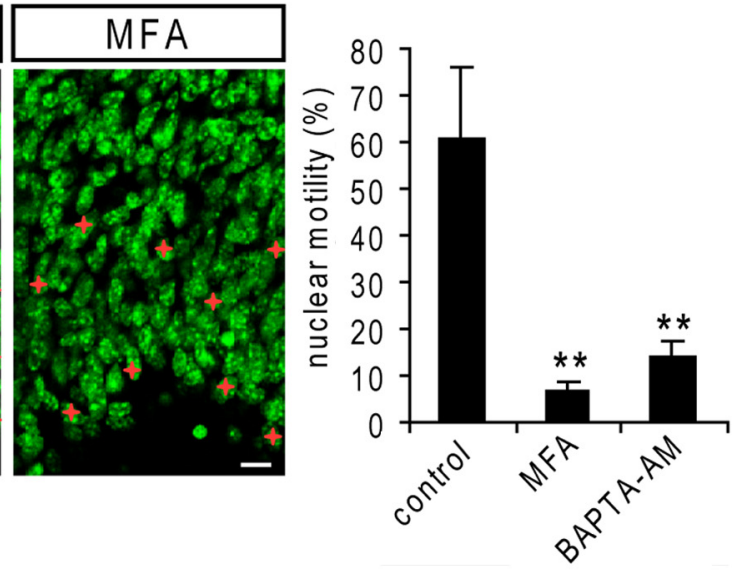

C1

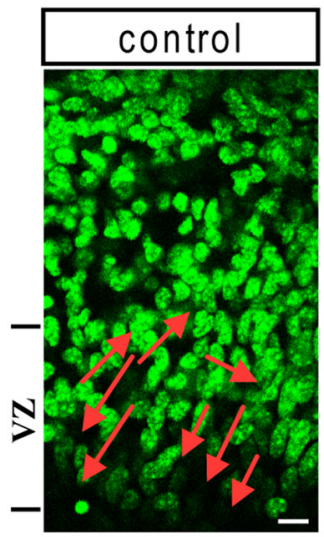

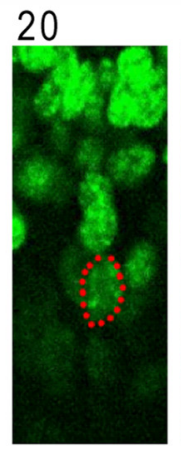
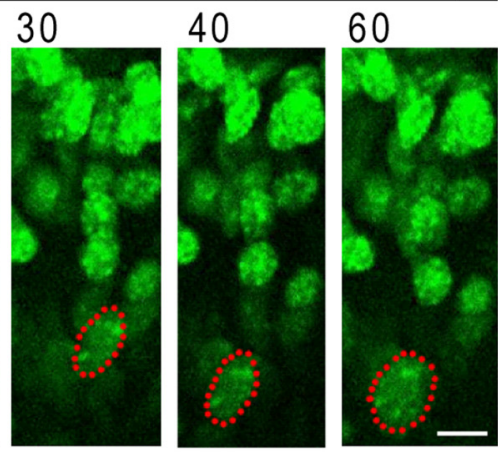

Figure 6. Interkinetic nuclear migration requires functional gap junctions/hemichannels in the VZ. The nuclei of the VZprecursors were labeled with Hoechst 33258, and time-lapse imagings were performed in acute slices in ACSF. A1, During the 10 min recording period, VZ precursors displaying nuclear motility are marked with red crosses in control and MFA-treated slice. Scale bar, $10 \mu \mathrm{m}$. $\mathbf{A 2}$, The percentage of VZ precursors displaying nuclear motility in control, MFA (100 $\mu \mathrm{m})$-, and BAPTA-AM (50 $\mu \mathrm{m}$; BAPTA)-treated slices ( ${ }^{* *} p<0.01 ; n=6$, 6 , and 4, respectively). $\boldsymbol{B}$, Illustration of an apically directed interkinetic nuclear migration from the upper portion of the VZ to the ventricular surface in control ACSF. Note the nuclear shape becomes more elongated during migration. Scale bar, $5 \mu \mathrm{m}$. C1, During the 60 min recording period, the cells displaying interkinetic nuclear migration in the VZ are indicated by arrows in the control, MFA (100 $\mu \mathrm{m})$-treated slices. The length of the arrow indicates the migration distance and the direction of the arrowhead indicates the migration direction. Scale bar, $10 \mu \mathrm{m}$. C2, The mean values of interkinetic nuclear migration speed and distance of the VZ precursors in control, MFA-, and BAPTAAM-treated slices $\left({ }^{* *} p<0.01,{ }^{*} p<0.05, n=4,5,3\right.$, respectively). Error bars indicate SEM. 

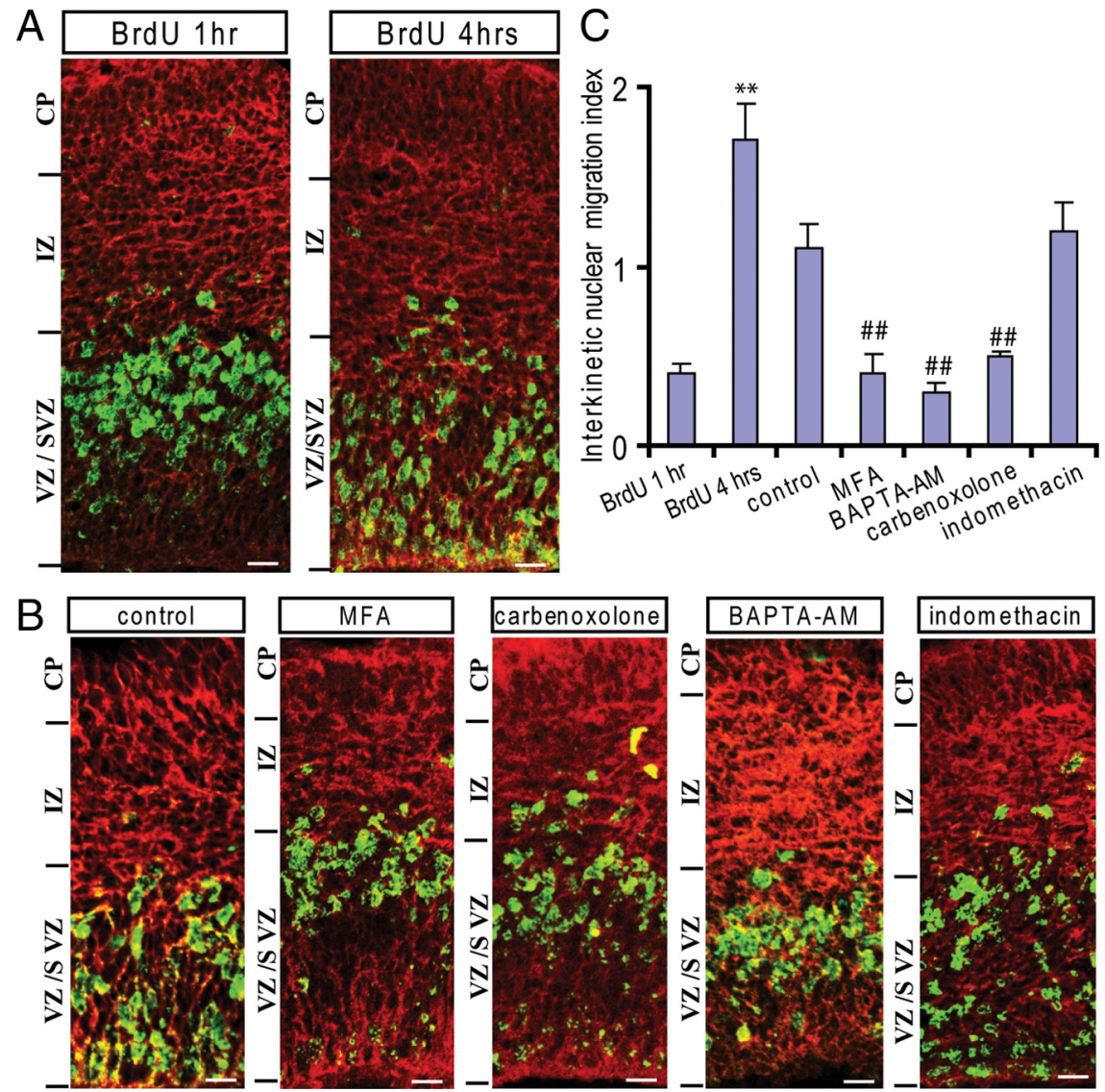

Figure 7. Blocking gap junctions/hemichannels inhibits the apically directed interkinetic nuclear migration in the VZ. $\boldsymbol{A}$, The S-phase cells were labeled by BrdU injection (50 mg/kg, i.p.) in pregnant mice (E15.5), and the position of the BrdU ${ }^{+}$nucleus was examined by immunostaining 1 and $4 \mathrm{~h}$ later. $\boldsymbol{A}$, The BrdU-labeled nuclei (green) are mainly located at the upper portion of the VZ/SVZ $1 \mathrm{~h}$ after BrdU injection. Many BrdU-labeled nuclei apically migrated to the lower portion of the VZ/SVZ4 $\mathrm{h}$ after BrdU injection in vivo. The outlines of the slices were illustrated by Tuj-1 staining (red). Scale bar, $10 \mu \mathrm{m}$. B, BrdU-labeled brain slices (1 h) were used for organotypic slice culture. Immunostaining for BrdU (green) in control, MFA (60 $\mu \mathrm{m})$-, CBX (60 $\mu \mathrm{m})-$, BAPTA-AM (50 $\mu \mathrm{m})$-, or indomethacin (100 $\mu \mathrm{m})$-incubated slices for $3 \mathrm{~h}$. Scalebar, $10 \mu \mathrm{m}$. C, The ratios of the BrdU immunostaining intensity of the lower half of the VZ/SVZ to the upperhalfafter BrdU injection (1 h), in vivo for $3 \mathrm{~h}\left({ }^{* *} p<0.01 ; n=6\right.$, respectively) and in culture for $3 \mathrm{~h}$ in control, MFA, BAPTA-AM, CBX, and indomethacin ${ }^{\# \#} p<0.01 ; n=7$, except $n=6$ for MFA). Error bars indicate SEM.

VZ/SVZ, and some reached the ventricular surface. The interkinetic nuclear migration index [i.e., the ratio of BrdU staining density between the lower and upper half portion of the VZ/SVZ (Cina et al., 2009)] is shown in Figure 7C. To test the effect of gap junctions/hemichannels on the interkinetic nuclear migration, we incubated these BrdU-labeled slices ( $1 \mathrm{~h}$ after BrdU injection) with vehicle or gap junction/hemichannel blockers. As shown in Figure $7 B$, many $\mathrm{BrdU}^{+}$nuclei migrated apically to the lower portion of the VZ/SVZ in the control slices after incubation for $3 \mathrm{~h}$. In slices treated with MFA $(60 \mu \mathrm{M})$, the migration of the $\mathrm{BrdU}^{+}$nuclei was delayed, and many of them stayed in the upper portion of the VZ/SVZ. Similar results were obtained with another gap junction/hemichannel blocker, CBX (100 $\mu \mathrm{M})$, and with BAPTA-AM $(50 \mu \mathrm{M})$ (Fig. $7 \mathrm{~B}, C)$. MFA is also known as a nonstereo antiinflammatory drug that reduces the $\mathrm{PGE} 2$ production by inhibition of cyclooxygenase. Thus, we examined the effect of indomethacin $(100 \mu \mathrm{M})$, another nonstereo antiinflammatory drug that has no effect on gap junctions/hemichannels. As shown in Figure 7, $B$ and $C$, the migration of the $\mathrm{BrdU}^{+}$nuclei to the lower portion of the VZ/SVZ was not affected. Together, our results suggest that functional gap junctions/hemichannels are essential for the apically directed interkinetic nuclear migration in the VZ precursors.

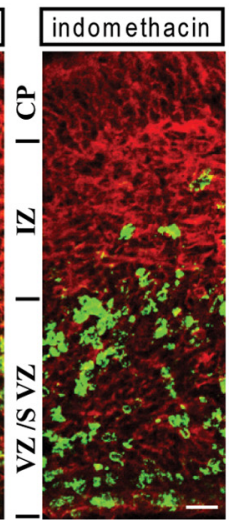

To exclude the possibility that the migration defect was attributable to cellular apoptosis, we performed terminal deoxynucleotidyl transferase-mediated biotinylated UTP nick end labeling (TUNEL) staining. In slices treated with MFA (60 $\mu \mathrm{M})$, the number of TUNEL ${ }^{+}$cells showed no significant difference compared with the control (supplemental Fig. S3, available at www.jneurosci.org as supplemental material).

\section{Blocking gap junctions/hemichannels induces changes of nuclear shape and phosphorylation of cdc42 in neural precursors}

During the $\mathrm{G}_{2}$ phase, the nuclei of the $\mathrm{VZ}$ precursors are pulled down by the assembled microtubules to the ventricular surface, which is associated with changes in nuclear shape (Xie et al., 2007). We analyzed the nuclear shape by measuring the ratio between nuclear length and width in the VZ precursors. The nuclei were labeled with Hoechst and imaged by $Z$-stack confocal scanning. As expected, many VZ precursors displayed olive-like elongated nuclei in the control slices. In contrast, the nuclei of VZ precursors lost their olivelike shape and became less elongated after short-term MFA treatment $(60 \mu \mathrm{M} ; 60$ min) (supplemental Fig. S4, available at www.jneurosci.org as supplemental material). To identify the $\mathrm{G}_{2}$-phase precursors in the VZ, coimmunostaining for $\mathrm{Ki} 67$ and BrdU in the embryonic brain labeled with BrdU (3 h after BrdU injection intraperitoneally at E15) was performed. All the BrdU ${ }^{+}$nuclei in the lower portion of the $\mathrm{VZ}$ were colocalized with Ki67 and displayed elongated olive-like shape (Fig. $8 A$ ). The nuclear length/width ratio in $\mathrm{Ki}^{+} 7^{+} \mathrm{BrdU}^{+} \mathrm{VZ}$ cells was quantified, which gave mean values of $1.82 \pm 0.06$ ( $n=48$ in 4 slices $)$ in the control slices (in ACSF for $60 \mathrm{~min}$ ) and $1.33 \pm 0.06(p<0.01$; $n=56$ in 4 slices) in MFA-treated slices (60 $\mu \mathrm{M} ; 60 \mathrm{~min}$ ) (Fig. $8 A, C)$. These results suggested that the pulling force for the apically directed nuclear migration was compromised after blocking gap junctions/hemichannels. We further detected the M-phase cells using immunostaining for $\mathrm{pH} 3$. In the control slices, almost all of the $\mathrm{pH}^{+}{ }^{+}$cells in the $\mathrm{VZ}$ located at the ventricular surface (Fig. $8 B$ ). In contrast, in slices treated with MFA $(60 \mu \mathrm{M} ; 3 \mathrm{~h})$, some $\mathrm{pH}^{+}$cells appeared above the ventricle surface (Fig. $8 B$ ) and the distance of the $\mathrm{pH}^{+}{ }^{+}$nuclei to the ventricular surface was significantly increased (Fig. $8 C$ ), suggesting that the apically directed interkinetic nuclear migration was inhibited in the $\mathrm{G}_{2}$ phase cells after blocking gap junctions/hemichannels.

Rho GTPases are key regulators of cytoskeletal dynamics and involved in many cellular processes, including cell motility and migration (Heasman et al., 2008). It has been shown that small Rho-GTPase cdc42 plays an essential role in the apically directed interkinetic nuclear migration in the VZ precursors (Cappello et al., 2006). Here, we tested whether blocking gap junctions/ hemichannels could affect the phosphorylation of cdc42 
(p-cdc42), the inactivated form of cdc42. In the control slices, the p-cdc42 was mainly detected in the intermediate zone (IZ) and with little in the VZ precursors (Fig. 8D1). In contrast, in slices treated with MFA (60 $\mu \mathrm{M} ; 60 \mathrm{~min})$, the p-cdc42 was significantly increased in the VZ (Fig. $8 \mathrm{D} 1$; supplemental data, available at www.jneurosci.org as supplemental material). The ratios of $\mathrm{p}$-cdc42 immunostaining density in the $\mathrm{VZ}$ against that in the IZ are shown in Figure 8D2. We also checked the expression of total cdc42 (tcdc42) and found no obvious difference between the control and the MFAtreated slices (Fig. 8D2; supplemental Fig. S5, available at www.jneurosci. org as supplemental material). To test whether Rho GTPase signaling is involved in the interkinetic nuclear migration in the $\mathrm{VZ}$ precursors, BrdUlabeled embryonic brain slices (E14; $1 \mathrm{~h}$ ) were incubated with Rho GTPase inhibitor Clostridium difficile toxin B (1 ng/ $\mathrm{ml}$ ). As shown in Figure $8 E$, toxin B completely abolished the apically directed interkinetic nuclear migration in the VZ. Similar to the effect of MFA, the $\mathrm{BrdU}^{+}$nuclei mainly locate at the upper portion of the $\mathrm{VZ}$ in toxin B-treated slices and the interkinetic nuclear migration index was significantly reduced (Fig. 8E1,E2). Consistent with the fact that activities of Rho-GTPases are regulated by intracellular $\mathrm{Ca}^{2+}$ signaling (Jin et al., 2005; Price et al., 2003), our results suggest that functional gap junctions/hemichannels might control the interkinetic nuclear migration by RhoGTPase cdc42 signaling.

\section{Knockdown of $\mathrm{Cx} 43$ affects interkinetic nuclear migration}

$\mathrm{Cx} 43$ is the major connexin in the mouse VZ precursors, including the radial glia, and is responsible for the gap junction coupling in the neuroepithelium (LoTurco and Kriegstein, 1991). We tested whether knockdown of $\mathrm{Cx} 43$ affects the interkinetic nuclear migration in the VZ precursors. We performed electroporation with enhanced green fluorescent protein (EGFP) plasmid and $\mathrm{Cx} 43$ or scrambled control shRNA in the $\mathrm{VZ}$ precursors at E15 and examined their nuclear shape and position at E16.5. As shown in Figure $9 A$, in the control brains, the $\mathrm{EGFP}^{+} \mathrm{VZ}$ precursors, identified by their foot-like processes to the ventricular surface, usually showed olive-like elongated cell bodies. The nuclei of these cells also displayed an olive-like shape and locate centrally within the cell bodies, which gave a mean length/width ratio of $2.11 \pm 0.05(n=21 ; p<0.01)$ (Fig. 9C). In contrast, in the brains electroporated with $\mathrm{Cx} 43 \mathrm{shRNA}$, the nuclei of $\mathrm{EGFP}^{+} \mathrm{VZ}$ precursors lost their olive-like shape and became less elongated (Fig. 9A), which

D1

E1 SEM.
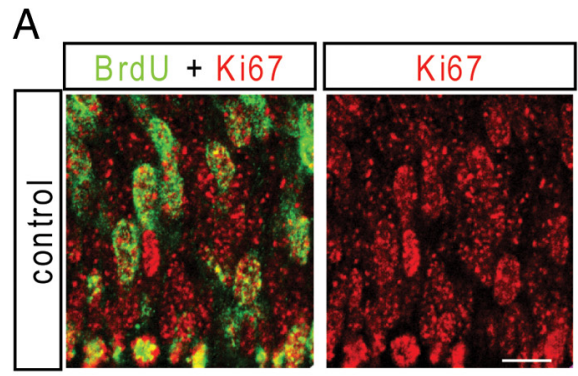

B
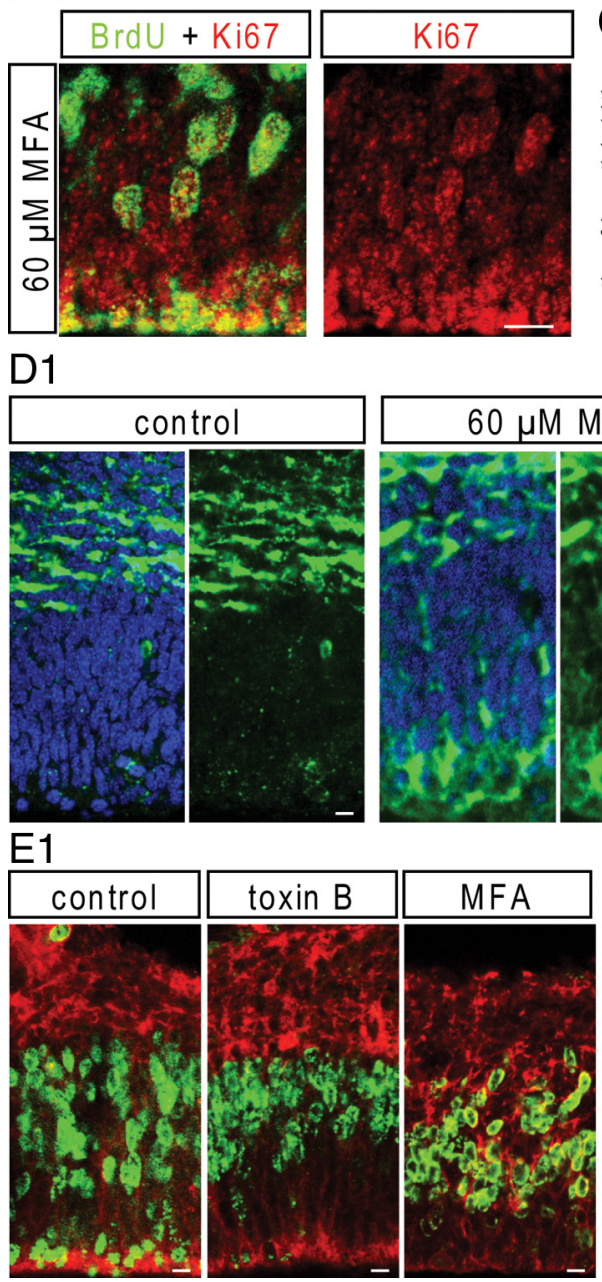

E2

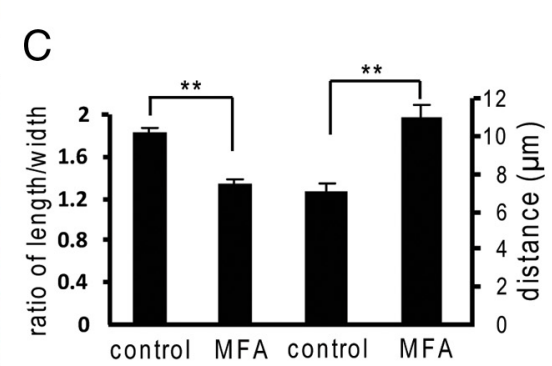

D2
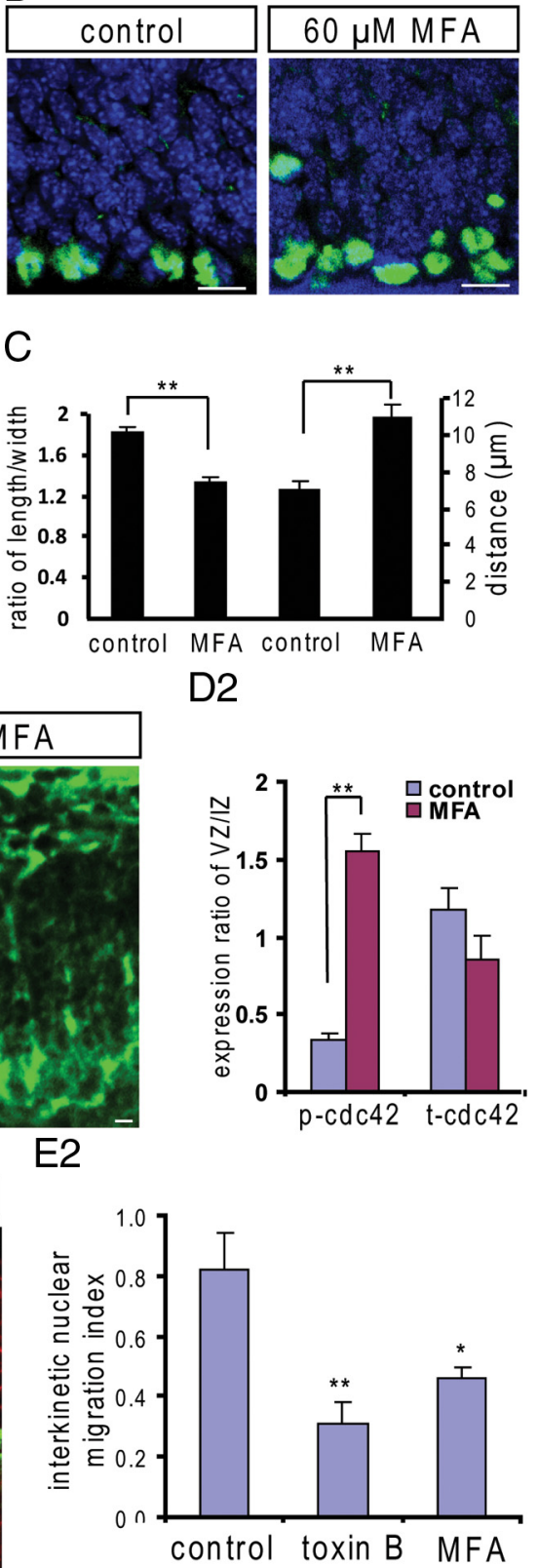

Figure 8. Blocking gap junctions/hemichannels changes the length/width ratio of nucleus and induces cdc42 phosphorylation. A, Coimmunostaining for Ki67 and BrdU in control and MFA-treated ( $60 \mu \mathrm{m} ; 60 \mathrm{~min}$ ) slices that had been labeled with BrdU $3 \mathrm{~h}$ after BrdU intraperitoneal injection at E15. The $\mathrm{G}_{2}$-phase cells in the VZ are identified by the Ki67 ${ }^{+} / \mathrm{BrdU}^{+}$nuclei. Scale bar, $10 \mu \mathrm{m}$. $B, p H 3$ staining in control and in MFA-treated slices $(60 \mu \mathrm{m} ; 3 \mathrm{~h}) . \mathrm{pH} 3^{+}$cells mainly located at ventricular surface within the VZ in the control slices. Some $\mathrm{pH}^{+}{ }^{+}$cells appeared in the VZabove the ventricular surface in MFA-treated slices. Scale bar, $10 \mu \mathrm{m}$. $\boldsymbol{C}$, The length/width ratios of nuclei of $\mathrm{G}_{2}$-phase cells in control and MFA-treated slices. ${ }^{* *} p<0.01 ; n=48,56$, respectively; and the mean distances of $\mathrm{pH} 3{ }^{+}$nuclei to the ventricle surface in control and in MFA-treated slices. ${ }^{* *} p<0.01 ; n=28,52$, respectively. D1, p-cdc42 immunostaining in control and MFA-treated slices. p-cdc42 is mainly expressed in the IZ cells in the control slices. MFA treatment ( $60 \mu \mathrm{m} ; 60 \mathrm{~min}$ ) induced $\mathrm{p}$-cdc42 increase in the VZ precursors. Scale bar, $10 \mu \mathrm{m}$. D2, The ratios of p-cdc42 signaling and $\mathrm{t}$-cdc42 signaling in the VZ to the IZ in control and MFA-treated slices. ${ }^{* *} p<0.01, n=8$ for $p$-cdc2 and $n=10$ for t-cdc42. $\boldsymbol{E}$, BrdU-labeled brain slices (1 h; E14) were used for slice culture. $E$ 1, Immunostaining for BrdU (green) in control, toxin B (1 $\mathrm{ng} / \mathrm{ml}$ )-, and MFA (60 $\mu \mathrm{m}$ )-incubated slices for $3 \mathrm{~h}$. Scale bar, $10 \mu \mathrm{m}$. E2, The ratios of the BrdU immunostaining density of the lower half to the upper half of the VZ/SVZ after culture for $3 \mathrm{~h}\left({ }^{*} p<0.05,{ }^{* *} p<0.01 ; n=7,6,6\right.$, respectively). Error bars indicate

gave a mean length/width ratio of $1.72 \pm 0.05(n=37)$ (Fig. 9C). Interestingly, these nuclei usually shifted to the upper portion of the cell bodies and made the cell shape like a thermo balloon. These results strongly suggest that the pulling force for the apically directed interkinetic nuclear migration was compromised after knockdown of Cx43. 


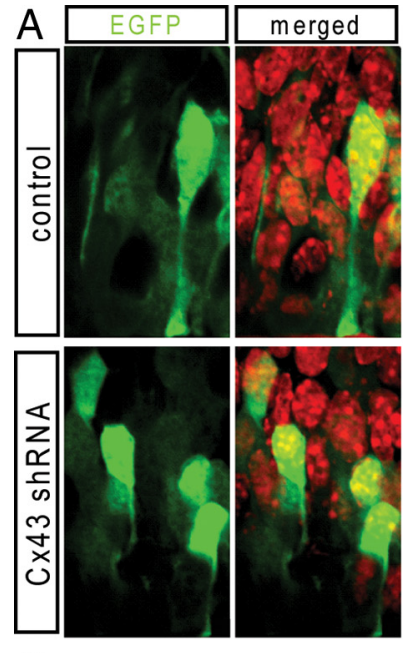

C

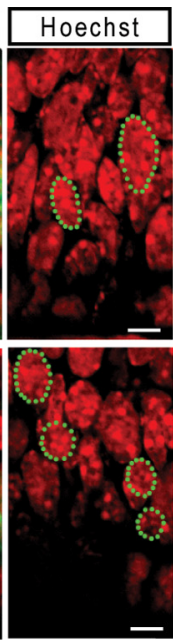

B2
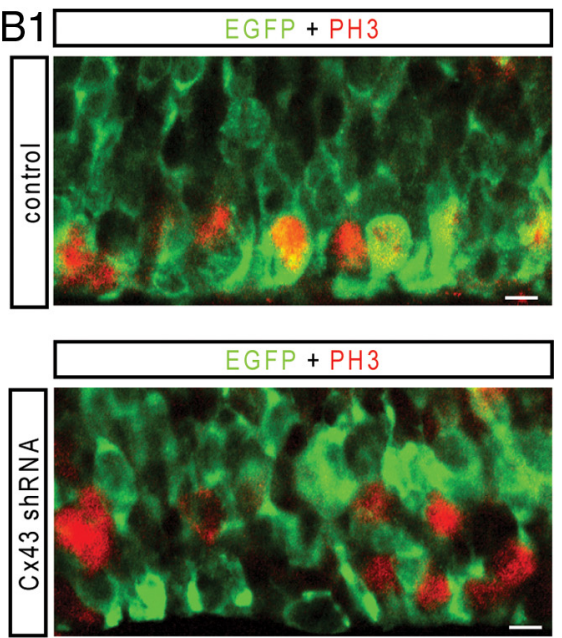

B3

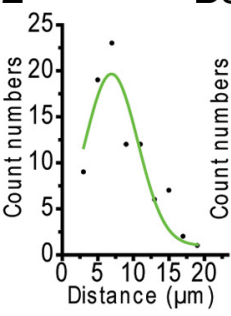

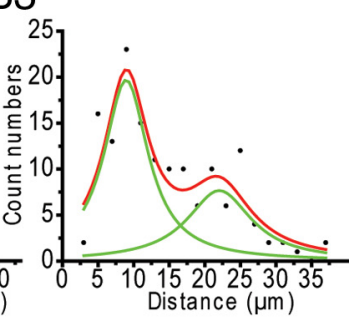

D2

control

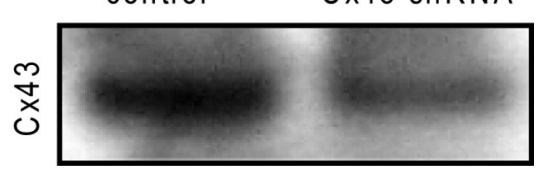

D1 control
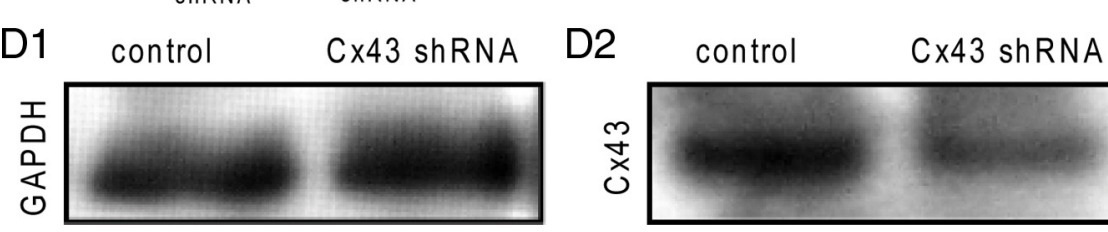

Figure 9. Knockdown of $\mathrm{C} x 43$ affects the apically directed interkinetic nuclear migration in the VZ precursors. EGFP plasmid with $C x 43$ or scrambled control shRNA plasmids were electroporated into the VZ precursors at E15, and the nuclei of the EGFP ${ }^{+}$VZ precursors were examined at E16.5. A, In the control brain, the EGFP ${ }^{+}$VZ precursors identified by the foot-like process attached to the ventricular surface display olive-like cell body and radially elongated nuclei. In $C \times 43$ shRNA electroporated brain, the EGFP ${ }^{+}$VZ precursors display thermo balloon-like cell body and less elongated nuclei that locate at the top of the cell body. Scale bar, $5 \mu \mathrm{m}$. $B$ 1, The M-phase cells in the VZ were detected by $\mathrm{pH} 3$ immunostaining (red). In the control brain, almost all of the $\mathrm{pH} 3{ }^{+}$cells in the VZ locate at the ventricular surface. In the $\mathrm{C} \times 43$ shRNA electroporated brain, some $\mathrm{pH} 3^{+}$cells are in the VZ above the ventricular surface. Scale bar, $5 \mu \mathrm{m}$. Count distributions of $\mathrm{pH}^{+}{ }^{+}$nuclei according to their distances to the ventricular surface in control (B2) and in Cx43 shRNA electroporated brain (B3). C, The nuclear length/width ratio in the VZ precursors in control and C $x 43$ shRNA electroporated brains ${ }^{* *} p<0.01 ; n=22,37$, respectively) and the mean value of the distances of $\mathrm{pH} 3{ }^{+}$nuclei to the ventricle surface in control and in $\left(x 43\right.$ shRNA electroporated brain $\left({ }^{* *} p<0.01 ; n=90,146\right.$, respectively). Error bars indicate SEM. D1, D2, Immunoblots for GAPDH and CX43 in N2a cells transfected with C $x 43$ full-length DNA, pCAG-EGFP and scramble or CX43 shRNA.

We further examined the nuclear positioning of the M-phase cells in the VZ by immunostaining for $\mathrm{pH} 3$. In the control brains, the $\mathrm{pH} 3{ }^{+}$cells mainly locate at the ventricular surface (Fig. 9B1). The mean value of the distances of the $\mathrm{pH}^{+}$nuclei to the ventricular surface is $8.3 \pm 0.4 \mu \mathrm{m}(n=90)$ (Fig. 9C) and their count distribution is shown in Figure 9B2. In CX43 shRNA electroporated brains, some $\mathrm{pH} 3^{+}$nuclei in the $\mathrm{VZ}$ cells were observed above the ventricular surface (Fig. 9B1), suggesting that these cells enter into the $\mathrm{M}$ phase before they migrate to the ventricular surface. The mean distance of the $\mathrm{pH} 3^{+}$nuclei to the ventricular surface was significantly increased to $14.5 \pm 0.6 \mu \mathrm{m}(n=146$; $p<0.01$ ) (Fig. 9C) and their count distribution showed a secondary peak (Fig. 9B3) indicating the mispositioning of a subgroup of mitosis cells in the VZ. We also examined the number of $\mathrm{pH} 3^{+}$ cells in the VZ and found no significant difference between the control and the Cx43 shRNA electroporated brain (data not shown), suggesting their overall entry into and exit out of mitosis were not affected. Finally, we tested whether overexpession of $\mathrm{Cx} 43$ could rescue the effect of Cx43 shRNA. As expected, the number of the mispositioned $\mathrm{pH} 3^{+}$nuclei above the ventricular surface reduced and more $\mathrm{pH}^{+}$cells located at the ventricular surface in slices coelectroporated with Cx43 full-length DNA (supplemental Fig. S6A1, available at www.jneurosci. org as supplemental material) and their average distance to the ventricular surface was significantly reduced (supplemental Fig. $\mathrm{S} 6 A 2$, available at www.jneurosci.org as supplemental material). Together, our results suggest that Cx43 is involved in the apically directed interkinetic nuclear migration in the VZ precursors.

To demonstrate the knockdown effect of Cx43 shRNA, we first transfected the mouse neuroblastoma cell line (N2a) with full-length DNA for mouse Cx43 and then cotransfected with pCAG-EGFP and scramble or Cx43 shRNA. The expression of CX43 in N2a cells was significantly reduced when cotransfected with $\mathrm{Cx} 43$ shRNA (Fig. 9D1,D2) $(p<0.01 ; n=4$, respectively), whereas the expression of EGFP was similar among each experiment (data not shown). The knockdown effect was further examined using immunostaining in the electroporated brain and the Cx43 expression was significantly reduced in $\mathrm{Cx} 43$ shRNA electroporated region (supplemental Fig. $S 6 B 1, B 2$, available at www.jneurosci.org as supplemental material). In addition, we observed that knockdown of $\mathrm{Cx} 43$ retarded migration of the postmitotic neurons into the cortical plate (data not shown), which is consistent with the previous observation (Elias et al., 2007; Cina et al., 2009).

\section{Discussion}

In the present study, we provide experimental evidence that gap junctions/hemichannels are involved in the apical phase of interkinetic nuclear migration in neural precursors. Our data suggest that regulation of apically directed interkinetic nuclear migration by intracellular $\mathrm{Ca}^{2+}$ signaling via both ATP release and $\mathrm{Ca}^{2+}$-mobilizing messenger diffusion may be an important mechanism by which functional gap junctions/hemichannels maintain the neural progenitor pool during their division.

Cytosolic $\mathrm{Ca}^{2+}$ signaling has previously been implicated in several aspects of nervous system development, including cell proliferation (Weissman et al., 2004; Pearson et al., 2005), differentiation ( $\mathrm{Gu}$ and Spitzer, 1995), migration (Komuro and Rakic, 1993), neurite outgrowth, and growth cone behavior (Gomez and Spitzer, 1999). In the present study, we confirmed the existence of $\mathrm{Ca}^{2+}$ signaling fluctuations in neural precursors of the VZ/SVZ (Owens and Kriegstein, 1998; Weissman et al., 2004). However, in addition, we have demonstrated the existence of highly dynamic spontaneous $\mathrm{Ca}^{2+}$ transients in situ at near-physiological condition $\left(2 \mathrm{mM} \mathrm{Ca}^{2+}\right)$. Furthermore, our results indicate that 
$\mathrm{Ca}^{2+}$ transients, observed in slices in vitro, might underestimate their effect in vivo. $\mathrm{P} 2 \mathrm{Y}$ receptor is expressed in the $\mathrm{VZ}$ precursors and extracellular ATP induces $\mathrm{Ca}^{2+}$ responses in these cells (Bittman et al., 1997; Weissman et al., 2004; Liu et al., 2008). We also demonstrated that ATP is spontaneously released via gap junctions/hemichannels and elevating cytosolic $\mathrm{Ca}^{2+}$ induces hemichannel opening in the VZ/SVZ precursors. In addition, $\mathrm{Ca}^{2+}$-mobilizing signaling can diffuse among the adjacent $\mathrm{VZ}$ cells. Thus, gap junctions/hemichannels are likely involved in the initiation, transfer, and amplification of the $\mathrm{Ca}^{2+}$ signaling via ATP release and $\mathrm{Ca}^{2+}$-mobilizing messenger diffusion, and generate $\mathrm{Ca}^{2+}$ oscillation in the VZ/SVZ precursors. The $\mathrm{Ca}^{2+}$ transients in $\mathrm{VZ} / \mathrm{SVZ}$ precursors mainly occur because of $\mathrm{Ca}^{2+}$ release from the ER via activation of $\mathrm{IP}_{3}$ receptor (Owens and Kriegstein, 1998; Weissman et al., 2004). Thus, various growth factors, hormones, and extracellular signaling that act on G-protein-coupled receptors may either alone or in combination contribute to the cytosolic $\mathrm{Ca}^{2+}$ signaling via the $\mathrm{Ca}^{2+}$-mobilizing second messenger $\mathrm{IP}_{3}$ in the neural precursors and thereby affect neurogenesis during cortical development.

Previous studies have shown that both actin- and microtubuleinvolved coupling between the nucleus and the centrosome are prerequisite for nuclear translocation during neuronal migration (Karfunkel, 1972; Messier and Auclair, 1973, 1974; Webster and Langman, 1978; Xie et al., 2007; Métin et al., 2008). The dynamics of actins and microtubules are modulated through a large number of cytoskeleton-associated proteins (Li and Gundersen, 2008) including cytoplasmic dynein and dynactin complex (Palazzo et al., 2001; Dujardin and Vallee, 2002; Del Bene et al., 2008). The cytosolic $\mathrm{Ca}^{2+}$ signaling might modulate the interkinetic nuclear migration by affecting either the assembly of microtubules or the transcription of genes via activation of small GTPases. For example, elevation of intracellular $\mathrm{Ca}^{2+}$ potently induces Rac activation; and lamellipodia formation induced by intracellular $\mathrm{Ca}^{2+}$ elevation is blocked by inhibition of Rac signaling, which indicates that intracellular $\mathrm{Ca}^{2+}$ might regulate the cytoskeleton system by activation of Rac (Evers et al., 2000; Price et al., 2003) including the small RhoGTPase cdc42 (Cappello et al., 2006). In the present study, we demonstrated that blocking of gap junctions/hemichannels decreases nuclear motility and impairs the apically directed interkinetic nuclear migration in the VZ, which is accompanied by an increase of p-cdc42, the inactivated form of Rho-GTPase cdc42. In addition, pharmacologically blocking of Rho GTPase signaling completely abolished the interkinetic nuclear migration. Therefore, functional gap junctions/hemichannels may modulate the interkinetic nuclear migration via small Rho-GTPase.

How do gap junctions/hemichannels control the "to" and "fro" interkinetic nuclear migration during neurogenesis? Several reports suggested that gap junction coupling is predominant in the $S / \mathrm{G}_{2}$-phase cells and diminishes in the $\mathrm{M}$-phase cells (Bittman et al., 1997; Bittman and LoTurco, 1999; Palazzo et al., 2001; Weissman et al., 2004). Correspondingly, the neural precursors in the upper strata of the VZ seem to display more intensive spontaneous $\mathrm{Ca}^{2+}$ transients. We propose a model that gap junction/hemichannel-mediated $\mathrm{Ca}^{2+}$ signaling in the $\mathrm{S} / \mathrm{G}_{2}$ phase cells enhances the interaction between the centrosome and the nucleus via microtubule assembly and promotes nuclear translocation toward the ventricular surface. In contrast, during the $M$ and $G_{1}$ phases, reduction in gap junction/hemichannel coupling may depolymerize the assembled microtubules and thus create conditions in favor of passive nuclear translocation, away from the ventricular surface. For example, mitotic divisions at the ventricular surface that increase cell density may displace the nuclei toward the upper strata of the $\mathrm{VZ}$ as suggested in the classical studies (Zwann et al., 1969). In contrast, migration in the apical direction is an active process. Consistent with this hypothesis, when the motor protein Dynactin-1 is disrupted in neuronal progenitors, their nuclei migrate more slowly toward the ventricular surface and more rapidly and at a longer distance away from the ventricular surface (Del Bene et al., 2008). If the apical nuclear migration depends on gap junction/hemichannel-mediated $\mathrm{Ca}^{2+}$ signaling, interfering with the activity of gap junction/hemichannel would affect both the VZ cells reentry into as well as their exit out of the cell cycle. Indeed, our study demonstrated that pharmacological blocking or genetic knockdown of gap junctions/hemichannels retards the nuclear migration of the $S / G_{2}$-phase cells in the upper strata of the VZ. In addition, disorganization of the VZ/SVZ and neuronal migration deficiencies in $\mathrm{Cx} 43$ genetic knock-out mice (WienckenBarger et al., 2007) further confirms that gap junctions/hemichannels are involved in both cellular (nuclear) migration and neuronal progenitor production in the VZ/SVZ.

Our model is also consistent with the reports that functional gap junctions/hemichannels are sensitive to a large spectrum of chemical and biophysical factors, such as cations (De Mello, 1983), pH, metabolite (Neyton and Trautmann, 1986), drugs (Harks et al., 2001), mechanical stimuli (Bao et al., 2004), and irradiation (Trosko et al., 1990). For instance, a low dose of ionizing radiation highly upregulated the expression of connexins (Azzam et al., 2003); and our group previously reported that exposure of the fetus to ionizing irradiation and ultrasound waves may cause misplacement of cortical neurons (Algan and Rakic, 1997; Ang et al., 2006). Abnormal neocortical development resulting from defective neurogenesis is associated with multiple neurological disorders, including autism, schizophrenia, and mental retardation (Rakic, 1988a; Gleeson and Walsh, 2000; Kriegstein, 2005). Therefore, interference with gap junction/hemichannelmediated $\mathrm{Ca}^{2+}$ signaling in neurogenesis may underlie the pathogenesis of neurological disorders caused by abnormal corticogenesis.

\section{References}

Alexandre H, Van Cauwenberge A, Mulnard J (1989) Involvement of microtubules and microfilaments in the control of the nuclear movement during maturation of mouse oocyte. Dev Biol 136:311-320.

Algan O, Rakic P (1997) Radiation-induced, lamina-specific deletion of neurons in the primate visual cortex. J Comp Neurol 381:335-352.

Ang ES Jr, Gluncic V, Duque A, Schafer ME, Rakic P (2006) Prenatal exposure to ultrasound waves impacts neuronal migration in mice. Proc Natl Acad Sci U S A 103:12903-12910.

Anselmi F, Hernandez VH, Crispino G, Seydel A, Ortolano S, Roper SD, Kessaris N, Richardson W, Rickheit G, Filippov MA, Monyer H, Mammano F (2008) ATP release through connexin hemichannels and gap junction transfer of second messengers propagate $\mathrm{Ca}^{2+}$ signals across the inner ear. Proc Natl Acad Sci U S A 105:18770-18775.

Azzam EI, de Toledo SM, Little JB (2003) Expression of CONNEXIN43 is highly sensitive to ionizing radiation and other environmental stresses. Cancer Res 63:7128-7135.

Bahrey HL, Moody WJ (2003) Voltage-gated currents, dye and electrical coupling in the embryonic mouse neocortex. Cereb Cortex 13:239-251.

Bao L, Sachs F, Dahl G (2004) Connexins are mechanosensitive. Am J Physiol Cell Physiol 287:C1389-C1395.

Belliveau DJ, Naus CC (1995) Cellular localization of gap junction mRNAs in developing rat brain. Dev Neurosci 17:81-96.

Bittman K, Owens DF, Kriegstein AR, LoTurco JJ (1997) Cell coupling and uncoupling in the ventricular zone of developing neocortex. J Neurosci 17:7037-7044.

Bittman KS, LoTurco JJ (1999) Differential regulation of connexin 26 and 43 in murine neocortical precursors. Cereb Cortex 9:188-195.

Buniello A, Montanaro D, Volinia S, Gasparini P, Marigo V (2004) An expression atlas of connexin genes in the mouse. Genomics 83:812-820.

Cappello S, Attardo A, Wu X, Iwasato T, Itohara S, Wilsch-Bräuninger M, 
Eilken HM, Rieger MA, Schroeder TT, Huttner WB, Brakebusch C, Götz M (2006) The Rho-GTPase cdc42 regulates neural progenitor fate at the apical surface. Nat Neurosci 9:1099-1107.

Cina C, Maass K, Theis M, Willecke K, Bechberger JF, Naus CC (2009) Involvement of the cytoplasmic C-terminal domain of connexin 43 in neuronal migration. J Neurosci 29:2009-2021.

Contreras JE, Sánchez HA, Eugenin EA, Speidel D, Theis M, Willecke K, Bukaukas FF, Bennett MV, Sáez JC (2002) Metabolic inhibition induces opening of unapposed connexin 43 gap junction hemichannels and reduces gap junctional communication in cortical astrocytes in culture. Proc Natl Acad Sci USA 99:495-500.

Del Bene F, Wehman AM, Link BA, Baier H (2008) Regulation of neurogenesis by interkinetic nuclear migration through an apical-basal notch gradient. Cell 134:1055-1065.

De Mello WC (1983) The role of cAMP and Ca on the modulation of junctional conductance-an integrated hypothesis. Cell Biol Int Rep 7:1033-1040.

De Vuyst E, Decrock E, Cabooter L, Dubyak GR, Naus CC, Evans WH, Leybaert L (2006) Intracellular calcium changes trigger connexin 32 hemichannel opening. EMBO J 25:34-44.

Dujardin DL, Vallee RB (2002) Dynein at the cortex. Curr Opin Cell Biol $14: 44-49$.

Elias LA, Wang DD, Kriegstein AR (2007) Gap junction adhesion is necessary for radial migration in the neocortex. Nature 448:901-907.

Eskandari S, Zampighi GA, Leung DW, Wright EM, Loo DD (2002) Inhibition of gap junction hemichannels by chloride channel blockers. J Membr Biol 185:93-102.

Evers EE, Zondag GC, Malliri A, Price LS, ten Klooster JP, van der Kammen RA, Collard JG (2000) Rho family proteins in cell adhesion and cell migration. Eur J Cancer 36:1269-1274.

Finkbeiner S (1992) Calcium waves in astrocytes-filling in the gaps. Neuron 8:1101-1108.

Gleeson JG, Walsh CA (2000) Neuronal migration disorders: from genetic diseases to developmental mechanisms. Trends Neurosci 23:352-359.

Gomez TM, Spitzer NC (1999) In vivo regulation of axon extension and pathfinding by growth-cone calcium transients. Nature 397:350-355.

Gu X, Spitzer NC (1995) Distinct aspects of neuronal differentiation encoded by frequency of spontaneous $\mathrm{Ca}^{2+}$ transients. Nature 375:784-787.

Haas B, Schipke CG, Peters O, Söhl G, Willecke K, Kettenmann H (2006) Activity-dependent ATP-waves in the mouse neocortex are independent from astrocytic calcium waves. Cereb Cortex 16:237-246.

Harks EGA, De Roos ADG, Peters PHJ, De Haan LH, Brouwer A, Ypey DL, Van Zoelen EJJ, Theuvenet APR (2001) Fenamates: a novel class of reversible gap junction blockers. J Pharmacol Exp Ther 298:1033-1041.

Haydar TF, Bambrick LL, Krueger BK, Rakic P (1999) Organotypic slice cultures for analysis of proliferation, cell death, and migration in the embryonic neocortex. Brain Res Brain Res Protoc 4:425-437.

Heasman SJ, Ridley AJ (2008) Mammalian Rho GTPases: new insights into their functions from in vivo studies. Nat Rev Mol Cell Biol 9:690-701.

Iacobas DA, Iacobas S, Urban-Maldonado M, Scemes E, Spray DC (2008) Similar transcriptomic alterations in $\mathrm{Cx} 43$ knockdown and knockout astrocytes. Cell Commun Adhes 15:195-206.

Jin M, Guan CB, Jiang YA, Chen G, Zhao CT, Cui K, Song YQ, Wu CP, Poo MM, Yuan XB (2005) $\mathrm{Ca}^{2+}$-dependent regulation of rho GTPases triggers turning of nerve growth cones. J Neurosci 25:2338-2347.

Karfunkel P (1972) The activity of microtubules and microfilaments in neurulation in the chick. J Exp Zool 181:289-301.

Komuro H, Rakic P (1993) Modulation of neuronal migration by NMDA receptors. Science 260:95-97.

Kriegstein AR (2005) Constructing circuits: neurogenesis and migration in the developing neocortex. Epilepsia 46:15-21.

Langman J, Guerrant RL, Freeman BG (1966) Behavior of neuroepithelial cells during closure of the neural tube. J Comp Neurol 127:399-411.

Lazarowski ER, Boucher RC, Harden TK (2000) Constitutive release of ATP and evidence for major contribution of ecto-nucleotide pyrophosphatase and nucleoside diphosphokinase to extracellular nucleotide concentrations. J Biol Chem 275:31061-31068.

Li R, Gundersen GG (2008) Beyond polymer polarity: how the cytoskeleton builds a polarized cell. Nat Rev Mol Cell Biol 9:860-873.

Liu X, Wang Q, Haydar TF, Bordey A (2005) Nonsynaptic GABA signaling in postnatal subventricular zone controls proliferation of GFAP-expressing progenitors. Nat Neurosci 8:1179-1187.
Liu X, Bolteus AJ, Balkin DM, Henschel O, Bordey A (2006) GFAPexpressing cells in the postnatal subventricular zone display a unique glial phenotype intermediate between radial glia and astrocytes. Glia 54:394-410.

Liu X, Hashimoto-Torii K, Torii M, Haydar TF, Rakic P (2008) The role of ATP signaling in the migration of intermediate neuronal progenitors to the neocortical subventricular zone. Proc Natl Acad Sci USA 105:11802-11807.

Lo Turco JJ, Kriegstein AR (1991) Clusters of coupled neuroblasts in embryonic neocortex. Science 252:563-566.

Messier PE, Auclair C (1973) Inhibition of nuclear migration in the absence of microtubules in the chick embryo. J Embryol Exp Morphol 30:661-671.

Messier PE, Auclair C (1974) Effect of cytochalasin B on interkinetic nuclear migration in the chick embryo. Dev Biol 36:218-223.

Métin C, Vallee RB, Rakic P, Bhide PG (2008) Modes and mishaps of neuronal migration in the mammalian brain. J Neurosci 28:11746-11752.

Nadarajah B, Jones AM, Evans WH, Parnavelas JG (1997) Differential expression of connexins during neocortical development and neuronal circuit formation. J Neurosci 17:3096-3111.

Neyton J, Trautmann A (1986) Physiological modulation of gap junction permeability. J Exp Biol 124:93-114.

Owens DF, Kriegstein AR (1998) Patterns of intracellular calcium fluctuation in precursor cells of the neocortical ventricular zone. J Neurosci 18:5374-5388.

Oyamada M, Oyamada Y, Takamatsu T (2005) Regulation of connexin expression. Biochim Biophys Acta 1719:6-23.

Palazzo AF, Joseph HL, Chen YJ, Dujardin DL, Alberts AS, Pfister KK, Vallee RB, Gundersen GG (2001) Cdc42, dynein, and dynactin regulate MTOC reorientation independent of Rho-regulated microtubule stabilization. Curr Biol 11:1536-1541.

Pangrsic T, Potokar M, Stenovec M, Kreft M, Fabbretti E, Nistri A, Pryazhnikov E, Khiroug L, Giniatullin R, Zorec R (2007) Exocytotic release of ATP from cultured astrocytes. J Biol Chem 282:28749-28758.

Pearson RA, Dale N, Llaudet E, Mobbs P (2005) ATP released via gap junction hemichannels from the pigment epithelium regulates neural retinal progenitor proliferation. Neuron 46:731-744.

Price LS, Langeslag M, ten Klooster JP, Hordijk PL, Jalink K, Collard JG (2003) Calcium signaling regulates translocation and activation of Rac. J Biol Chem 278:39413-39421.

Rakic P (1988a) Defects of neuronal migration and the pathogenesis of cortical malformations. Prog Brain Res 73:15-37.

Rakic P (1988b) Specification of cerebral cortical areas. Science 241:170-176.

Sidman RL, Rakic P (1973) Neuronal migration, with special reference to developing human brain: a review 4. Brain Res 62:1-35.

Solecki DJ, Model L, Gaetz J, Kapoor TM, Hatten ME (2004) Par6alpha signaling controls glial-guided neuronal migration. Nat Neurosci 7:1195-1203.

Spray DC, Ye ZC, Ransom BR (2006) Functional connexin "hemichannels": a critical appraisal. Glia 54:758-773.

Stout CE, Constatin JL, Naus CC, Charles AC (2002) Intercellular calcium signaling in astrocytes via ATP release through connexin hemichannels. J Biol Chem 277:10482-10488.

Trosko JE, Chang CC, Madhukar BV (1990) Modulation of intercellular communication during radiation and chemical carcinogenesis. Radiat Res 123:241-251.

Watterson BF (1966) Action on alcoholism. Ann N Y Acad Sci 133:880-882.

Webster W, Langman J (1978) The effect of cytochalasin B on the neuroepithelial cells of the mouse embryo. Am J Anat 152:209-221.

Weissman TA, Riquelme PA, Ivic L, Flint AC, Kriegstein AR (2004) Calcium waves propagate through radial glial cells and modulate proliferation in the developing neocortex. Neuron 43:647-661.

Wiencken-Barger AE, Djukic B, Casper KB, McCarthy KD (2007) A role for Connexin43 during neurodevelopment. Glia 55:675-686.

Xie Z, Moy LY, Sanada K, Zhou Y, Buchman JJ, Tsai LH (2007) Cep120 and TACCs control interkinetic nuclear migration and the neural progenitor pool. Neuron 56:79-93.

Zhao HB (2005) Connexin26 is responsible for anionic molecule permeability in the cochlea for intercellular signalling and metabolic communications. Eur J Neurosci 21:1859-1868.

Zwann J, Bryan PR, Pearce TL (1969) Interkinetic nuclear migration during the early stage of lens formation in the chicken embryo. J Embryol Exp Morphol 21:71-83. 